\author{
Павло Гриценко \\ Інститут української мови НАН України \\ Київ \\ ORCID: 0000-0002-5363-6585; hrytsenko_pavlo@ukr.net
}

\title{
Карпатоукраїнська словосполука біла дівка в південнослов'янському контексті
}

\begin{abstract}
Реферат: Студія є ескізним розглядом окремих питань із широкої проблематики карпатобалканіки. За матеріалами словосполучення біла дівка та інших номінацій із компонентом *běl- у фольклорних текстах показано спеціалізацію семантики кольороназви; прокоментовано окремі лінії змін значень *běl- в українськокарпатському просторі, а також виявлені в болгарському, македонському і сербському мовно-культурних континуумах паралелі й відповідники цим процесам. Окреслено особливості лінгвальної й етнокультурної інформації, що містять фольклорні тексти, прийоми iii використання в дослідженні діалектного континууму однієї мови та генетично споріднених мов.
\end{abstract}

Ключові слова: слово і словосполука у фольклорному тексті, кольороназви, *běl- (білий), фольклор (українські, болгарські, македонські, сербські пісні), карпатобалканіка, ареал, ізоглоса.

\begin{abstract}
The Carpathian Ukrainian collocation біла дівка in the Southern Slavonic context. The collocation біла дівка (synonymous with гарна дівчина, кохана дівчина) and its correlative білий хлопеиь, легінь are popular in the song folklore of the Ukrainian Carpathian Mountains. In the Ukrainian dialectal continuum, these frequent structural elements of the kolomyika songs belong to the Carpathian regional lexis. In Carpathian songs about love and affection, the meaning "beautiful, positive" conveyed by білий occurs in the phrase *біла дівка as well as many phrasal names containing it.

The folklore of every ethnic community is unique with respect to its content (i.e. plots and themes), language, and imagery. At the same time, behind the uniqueness of folk songs of different people, there are sometimes common features arising at various times and for different reasons. These features is a specific subject for comparative-historical research. Bulgarian, Macedonian, and Serbian songs reflect a mode of using *bél- to express the notion of love and affection as well as the related values; this bears a resemblance to the Carpathian Ukrainian pattern. These folklore traditions share a more or less similar way of using the qualifier *běl- referring to a beautiful beloved maiden, as well as attributes, circumstances, and processes which, taken together, represent a large axiological "white space matrix" of love songs (carrying markedly positive connotations). Here, the qualifier *bél- is among the principal means of implementation of the semantic features "beautiful" and "positive", while its synonymic relations to the other items conveying the same meaning are ethnos-specific.

The qualifier *bél- in the collocation *біла дівка and its permanent presence in the structure of the other nominative items represent the Ukrainian-Carpathian-Bulgarian-Macedonian-Serbian isogloss, thus increasing the number of integral, linguistic and cultural Ukrainian-Carpathian-Southern-Slavonic entities. The meaning of the isogloss's invariant is modified and extended by names, collocations, and concepts widely manifested in Carpathian songs as well as in separate Southern Slavonic folklore traditions. Equally topical is the study of the isogloss's structure (i.e. the topography of relevant elements and phenomena as well as their areal distribution and functioning) and of the prerequisites for the emergence of similar linguistic items and phenomena within different languages and cultures. This is
\end{abstract}


owing either to their mutually independent convergent development, the preservation of the homogeneous historical heritage of the earlier periods, or to the interaction between languages and their dialects. The intensity and sources of these influences are often evidenced by the isogloss's specific characteristics.

As a result of the appearance of "beautiful" and "positive" as the meanings of *bell- and their occurrence in the Carpathian-Balkan area, the issue of the origin of these features within each language of this area becomes topical. An investigation of this issue will show whether they are secondary in relation to, and derivative from, the underlying meaning of colour, or maybe they derive from the archaic syncretic semantics of білий "shining = light = beautiful".

The unique, i.e. exclusive, structural elements of each Slavonic language are not only indicative of the specificity of their evolution but are also instrumental for comparative analysis aimed at establishing the degree of identity or similarity between languages and cultures. The feasibility of isoglosses / isopragms evidenced by folklore texts and ethnographic materials correlates with the exhaustiveness and comparability of basic data corpora of individual Slavonic dialectal continuums.

Keywords: word and collocation in the folklore text, colour names, *běl- (white), folklore (Ukrainian, Bulgarian, Macedonian and Serbian songs), Carpatho-Balcanica, area, isogloss.

Для з'ясування диференціації діалектного континууму мови увагу зосереджують насамперед на тих структурних елементах, процесах і явищах, які в говірках оприявнені в багатьох словоформах, пізнавані як риси окремого діалекту чи ширшого ареалу; такі лінгвальні ознаки використовують у класифікаційних побудовах, типологічних студіях. Водночас у кожній говірці функціонує багато рідковживаних мовних одиниць, засвідчених в обмеженій кількості словоформ або ж використовуваних лише в окремих сферах спілкування чи комунікативних ситуаціях: вони творять значну за обсягом периферію в структурі кожної говірки. Непоодинокими $є$ ситуації, коли мовний елемент одними своїми рисами (формальними, функційними) належить до кола центральних ознак говірки / діалекту, іншими - до периферійних. Серед периферійних рідковживаних мовних елементів трапляються такі, які є важливими для пізнання сучасного стану окремої говірки чи діалекту в цілому, їх формування, еволюції, проте вони здебільшого залишаються поза увагою дослідників, їх лише спорадично використовують у дескрипції говірок, зіставних та порівняльно-історичних студіях.

Ілюстрацією здатності узвичаєних у структурі мови лексем, словоформ акумулювати різнопланову, інколи - непередбачувану інформацію може слугувати лексема білий (-a), що належить до ядра словникового складу українських діалектів і літературної мови, зберігає впродовж тривалого функціонування базову семантику ('[предмет] кольору крейди, молока, снігу; протилежний до чорний’), має високу словотвірну продуктивність ${ }^{1}$, розгалужену сполучуваність та низку похідних значень. Припускаємо, що широке вживання лексеми білий у різних стилях літературної мови та в діалектній комунікації, визначеність іiї узуального ядра семантики не сприяли цілеспрямованому зацікавленню лінгвістів цим словом, оскільки відоме й узвичаєне не мотивує до спеціальних пошуків.

Українські фольклорні тексти карпатського ареалу, у яких лексема білий засвідчила неузуальну для українського континууму сполучуваність i, як наслідок, - не узвичаєні значення та їхні відтінки, привернули до цієї лексеми спеціальну увагу.

1 У кореневому гніздовому словнику української літературної мови подано 468 дериватів від біл(Карпіловська 2002, 57-63). 
Загальновідомо, що в народних піснях як окремій специфічній сфері реалізації мови часто трапляються словосполуки, не поширені в літературному стандарті та щоденному діалектному мовленні, хоча аналіз такої синтактики зазвичай доводить закономірне й структурно вмотивоване їх постання та функціонування.

1.

У карпатському ареалі українського мовно-культурного континууму серед численних номінативних одиниць із компонентом біл- (однослівних дериватів, дво- чи багатослівних назв) із різних ідеографічних сфер народного лексикону поширені словосполуки біла дівка / дівка біла, біла молодиия, білий хлопещь, білий летінь (далі в тексті цей тип номінацій умовно подаємо як *біла дівка), які для носіїв культури 3-поза карпатського регіону видаються дещо незвичними, напр.:

Забавляйся, бі́ла ді́вко, доки́-с молоденька / Бо забудеш ба́влінячко, як буде маленьке (Росішка Рахів - Грицак)'; Ой, шо ти, біла дівко, сумуєш, сумуєш, / Та за мене, молодого, місяці рахуєш? (Вел. Бичків Рахів - Куняк, 199); Ой відки ты, дівко біла, чи ни з Волосянки, / Кобы мині постелила на піч бобов'янки (Волосянка Сколе - Сокіла , 27); Ей білі молодищі / та білі, та бїлі / Ко вас буде цюльовати / кождої неді́лі (Сокирниця Хуст - Грицак); Та коли м ти, білий хлопче, писала писемце / Та як листок на трепетї дрижало ми серце (Росішка Рахів - Грицак); Не скажу ти, білий хлопче, не меш мочи спати (Богдан-Вовчій Рахів - Куняк, 210); Даймо собі посадити [біля хати дуба] та й обгородити / Щоби знали білі хлопиі, до кого ходити (Керецьки Свалява - К, 73); Ой летіню, легінику, летіню біленький, / Позич мені сороківець на мід солоденький (Вел. Ключів Коломия - Савчук, 29); Ий білый литінику, побануйеш за мнов, йак овечка біл'уменка за зеленов травов (Довге Іршава - Грицак 2017, 229).

Наведені зразки вживання словосполуки типу *біла дівка взято з коломийок, які є основною сферою їх використання, хоча зрідка засвідчені також у піснях інших жанрів; у повсякденному мовленні їх функціонування допустиме, хоча в опублікованих джерелах його не фіксовано. Контексти вживання *біла дівка засвідчують, що в біл- актуалізовано не узуальну семантику 'білий колір', а передано смисли, які не чітко структуровано, проте можуть бути співвіднесені зі значеннями 'кохана (коханий)', 'гарна (гарний)', 'мила (милий)' у їхньому тісному поєднанні, синкретизмі. Якби смисловим центром словосполуки *біла дівка був

2 Локалізацію матеріалу, його графіку та тлумачення окремих лексем і виразів подано за цитованими джерелами.

3 У фольклорних текстах семантика лексеми молодиия не завжди чітко окреслена; інколи не ясно, чи це позначення заміжньої молодої жінки чи дівчини, оскільки в укр. пд.-зх. говірках ця лексема відома з різними значеннями: у закарпат. 'молода заміжня жінка', ‘молода на весіллі' (Сабадош 2008, 175); у надсян. гов. mołod'yc'a 'молода на весіллі' (i mołod'ec 'молодий на весіллі') (Rieger 2017, II, m. 138, 139), у гуц. гов. давніше було зафіксовано mołod'yc'a 'покритка' (Rieger 1996, m. 25). 
колір (насамперед волосся, а також шкіри людини), то в піснях цього тематичного циклу були б так само широко вербалізовані інші кольори, зокрема кольори волосся - чорн-, рус-; однак такі назви в карпатських коломийках трапляються зрідка, до того ж без тих виразних конотацій, що супроводжують вживання словосполук *біла дівка $a^{4}$; на спеціальну увагу заслуговують синтагми 3 похідними від жовт- (дівка з жовтими волоси, жовті коси, жовтокоса дівка), які неодноразово зафіксовані в піснях карпатського регіону. Зміна семантичних домінант лексеми білий - від «колір» до «оцінка, аксіація» - у словосполуці *біла дівка підпорядкована досягненню виразного характеризування об'єкта називання відповідно до канонів поетики фольклору.

Для кольороназв вихід за межі первісного (чи узуального) семантичного поля, розвиток і закріплення похідних значень зумовлені високим функційним навантаженням кольорів як у повсякденному позакультурному дискурсі (у профанному сприйманні й оцінюванні реалій), так і в традиційній культурі, де сформувалися розгалужені парадигми символьних функцій кольорів і їхніх назв - кольорові коди культури (докладніше в: Белова 2012). Символізація кольорів - явище універсальне, реалізація якого в культурах різних народів зумовлює появу типологічно однакових / близьких рис на тлі численних не повторюваних, ексклюзивних ознак (див.: Алмалех 1997). Кольорові коди народної культури завжди мають мовну вербалізацію; кореляція, взаємовпливи мови і культури зумовлюють архітектоніку номінативних / семантичних полів кольороназв, їх сполучуваність (синтактику), метафоризацію, закріплення у фразеологічних одиницях, пареміях. Окреслення функційного поля, особливо - семантичного потенціалу основ кольороназв, виявлення спільних і відмінних для різних мов / діалектів ознак уможливлює реконструкцію умов і напрямків їх еволюції в кожному мовно-культурному ареалі. Визначення семантичного поля назв кольорів, зокрема 3 урахуванням усталених словосполучень та дериватів, стосовно кожної мови є складним завданням (див.: Ивић 1999), особливо - з'ясування напрямків та послідовності еволюції значень, передумов постання метафоричних номінацій із використанням кольоративів, що нерідко належать до глибоко архаїчних, а їх виникнення не є самоочевидним. Ілюстрацією складних семантичних перетворень кольороназви běl- можуть слугувати сербські словосполуки беле пчеле [білі бджоли] 'найдальші нащадки'5 і бели орао [білий орел] 'найстарший предок' зі зневиразненим пов'язанням із вихідним значенням běl- '[реалія] білого кольору’ (див.: Белетић 2001): закріплені структурами сталих словосполук такі семантичні перетворення, ймовірно, належать до глибокої архаїки, є відгомоном давньої картини світу сербів.

4 У великому зібранні Я. Куняка (4881 коломийка з карпатського регіону) на тлі кількох сотень прикладів використання похідних від біл- (*біла дівка) зафіксовано лише кілька контекстів уживання словосполук з означенням чорн-, у яких проступає семантика кольору, напр.: Куди я мав повернути, люльку прикурити, / Ще й чорненьку дівчиноньку до себе тулити (Гвізд Надвірна - Куняк, 137).

5 Зауважимо, що в серб. пірот. діал. бе́ла пчела́ відома зі значенням 'правнукові син чи донька': После прауну́ка су беле пче́ла (Златковић 2014, 51); у діал. герцеговин. для бе́ла пчела́ С. Пуїч зафіксував інше близьке значення 'правнук чи праправнук' та вираз дожи́вјет бӥјелије че́ла̄ [дожити до білих бджіл] ‘дожити до глибокої старости, дочекатися далеких нащадків’ (Пујић 2013, 505). 
Семантика багатьох назв кольорів поєднує різні складники - власне лексичне, прагматичне, символічне, культурне та енциклопедичне «співзначення», урахування сукупності й узаємодії яких здатне забезпечити цілісне дослідження семантичного поля лексеми, виявити закономірності іiі функціонування (докладніше в: Толстая 2008, 248-249). На конфігурацію, зміни семантичних полів кольороназв впливають як внутрішньомовні чинники - системні відношення в межах лексико-семантичної групи (для формування і функціонування семантики біл- важливою $є$ антонімія 3 чорн- ${ }^{6}$ ), їх закріплення як складників вторинних назв, входження до усталених словосполук, так і чинники позамовні, насамперед належність до парадигми традиційної культури, де відбувається зміна профанного сегмента функційного поля мовних одиниць під впливом відповідних культурних кодів (Толстой 1995). У просторі культури кольороназва набуває символьних функцій i водночас впливає на структуру, зміст усього культурного тексту. Наприклад, у слов'янській міфології оцінка персонажа народної демонології може залежати від того, якого він кольору - білий чи чорний; відповідно - десигнат «маркується як позитивний чи негативний», хоча встановити таку залежність вдається не завжди, оскільки «ясної причини, чому та сама демонічна істота буває то білою, то чорною, немає. Пояснення необхідно шукати в значеннях самого білого і чорного, тобто в просторі, де ці кольори використовуються, поширені» (Раденкович 2007, 88).

2.

Словосполуки *біла дівка з карпатських коломийок привернули увагу тим, що:

а) це усталена номінація з неузуальним на тлі українськомовного континууму поєднанням компонентів;

б) численні контексти вживання словосполуки засвідчують сталий зв'язок і3 семантичним простором «кохана, гарна [особа] / кохання, приязнь», відтак із концептами «кохати / кохання» та «гарний / позитивний»;

в) у переважній більшості словосполуки *біла дівка мають виразну оцінну конотацію, що є складником загального оцінного простору пісні;

г) цим словосполукам притаманне формальне варіювання, широкі синонімічні зв’язки з іншими засобами вербалізації відповідної семантики й аксіації;

г) *біла дівка є виразною рисою народних пісень, що зафіксована в багатьох віддалених між собою населених пунктах широкого карпатського ареалу (Підкарпаття, Закарпаття, зрідка - суміжні ареали); найчастіше - це коломийки, зрідка - пісні

${ }^{6}$ Антонімія семантичних полів *běl- і *čern- нерідко охоплює не лише т. зв. етимонні семеми (позначення кольору), а й вторинні, переносні значення, напр., у болг. мові «ці антоніми позначають поняття етики (добро / зло); естетики (красиво / некрасиво, потворно); емоційне буття людини (щастя / нещастя, приємно / неприємно)» (Коспартова 1972, 85); закономірно, що на контрасті значень цих лексем постали виразні фольклорні образи. 
інших жанрів. Зауважимо, що коломийки як яскраве явище пісенної культури українців у карпатському ареалі на поч. XXI ст. не перетворилися в етнографічний архаїзм: активне використання традиційних текстів поєднується 3 новими пісенними зразками, які творяться експромтом, імпровізовано (Лесюк 2008, 316), що є передумовою появи нових контекстів уживання *біла дівка.

У реєстрах українських діалектних лексиконів словосполуку *біла дівка як вокабулу не наведено, що, ймовірно, зумовлено традицією відокремлення фольклору від діалектного мовлення без уваги до їхніх генетичних взаємозв'язків та особливостей функціонування. Окремі коментарі до семантики цієї словосполуки подано в описах поетики народних пісень; зокрема, зауважено, що в бойківських коломийках епітет білий, біленький є частовживаним і має значення 'гарний', 'вродливий' (біла дівка, білий хлопещь, біленька дівчина, дитина біленька тощо), а також на його основі утворений відповідний іменник білявина (білявочка) 'красуня, кохана, мила’ (Кирчів 2002, 87); близькі до наведених коментарі подано в: (Мушкетик 2013, 150) ${ }^{7}$.

Контексти використання *біла дівка різноманітні; конотації словосполук можуть коливатися від полюса виразно позитивної характеристики об'єкта називання до його нейтрального позначення і далі - до протилежного полюса - негативного оцінювання (останнє - у текстах іронічного, глузливого спрямування). Тому в одних ситуаціях *біла дівка чітко співвіднесена із семантичним простором «кохана, гарна [особа]», іiі використання часто супроводжується засобами посилення оцінки, експресії; в інших - відсутня виразна конотація, словосполука функційно тотожна лексемі дівчина (чи хлопець, легінь); ще в інших наявний контраст між очікуваним позитивним спрямуванням тексту, зумовленим використанням *біла дівка, з іншими елементами тексту, насамперед стилістично виразно зниженими, 3 «негативним» значенням (прагматика пісні може змінюватися від легкої іронії до сарказму й гострої негаціi).

Позитивна конотація *біла дівка у фольклорному дискурсі усталилася, набула синонімічних зв'язків з іншими засобами позитивного (схвального) оцінювання об'єкта номінації, переросла в окрему сему 'гарний / коханий' із не зовсім чітко

7 Тексти пісень із цими словосполуками відтворено в численних виданнях XIX-XX ст., зокрема це відомі зібрання Я. Головацького (1878), де Воллана (1885), фундаментальне тритомне видання В. Гнатюка (1905-1907); пізніше було опубліковано чимало зібрань, серед яких значною кількістю власних записів вирізняються колекції Я. Куняка (2006) - з багатьох населених пунктів, та М. Савчука (1999), В. Сокола (1998-2016) - з окремих сіл; в академічному виданні коломийок (1969) об'єднано зразки пісень 3 усієї України (К). Окремі рукописні зібрання текстів коломийок (частина записів Я. Куняка; фольклорні матеріали С. Пушика) зберігаються у приватних колекціях; коломийки із Закарпаття, записані М. Грицаком, зберігаються в Інституті мистецтвознавства, фольклористики та етнології ім. М.Т. Рильського НАН України (од. зб. 383), чимало з яких опубліковано в (К); багато коломийок М. Грицак використав для ілюстрування слововживання в «Словнику українських говірок Закарпатської обл.». 
окресленими зовнішніми контурами семантики; натомість у контекстах негативного спрямування не сформувалося окремого значення лексеми білий, що могло б уплинути на структуру семантичного поля; пор. контексти з різною конотацією:

позитивна оцінка: Та віткі ти, біла дівко, та віткі, та віткі. Ци не з тойі полонини, што родит' йагідки (Чинадієво Мукачів - Грицак); То-ісь ми ся, дівко біла, та й ісподобала, / Та як несла воду д’горі - ни відпочивала; Ой ни бійся, дівко біла, лютого морозу, / Я під твої білі ніжки хустинку підложу (Волосянка Сколе - Сокіл ${ }^{\mathrm{s}}, 482,489$ );

неувиразнена (нейтральна) оцінка: Та ко го́ден нын'i пи́ти, а за́втра роби́ти, / тот с'а го́дин білуй д’'виі в ву́чка подиви́ти (Буштино Тячів - Грицак); Ой співай, біла дівко, як зимі, так літі, / Тілко маєш, дівчиночко, гаразду на світі (Закарпаття - Грицак); Ой ни ходи, більй хлопче, горою за мною, / Бо я бідна, а ты богач, ни пара з тобою (Волосянка Сколе - Сокілв, 567); Ой стій ти, білий хлопче / Та не копли зіля, / Дівчина тя зчаловала, / В дівчіни весіля (Закарпаття - Ребошапка, 92);

негативна оцінка: Ой душко, білявочко, тогди будеш моя, / Як Говерла 3 Чорногоров підуть гоцацоя ('як гори затанцюють') (Луги Рахів - Грицак); Не журися, біла дівко, не жури, не жури, / Аби-с доти дівочила, щоб пуджіла кури ('аби доти не вийшла заміж, доки не зістарієшся настільки, щоб тебе лякалися навіть кури’) (Нересниця Тячів - Куняк, 195); Та заткайсьи, біла дівко, ни знаєш співати, / Гач у кучу ('йди у хлів’) межи свині валови ('корито для годівлі свиней') лизати (Луги Рахів - Грицак); Ой бїa біл'aви́но, громы бы т’а ўби́ли, / И йедному с' ни валоўчна ('не належна'), а три т’а л’уби́ли (Черна Виноградів - Грицак); Ти гадаиш, білий хлопчи, що ти в силі́ оден, / Що ти мене молодиньку любити ни годин (Стримба Рахів - Грицак).

Зауважимо, що в називанні коханої дівчини в карпатських коломийках використання словосполук з означенням біл- відчутно переважає над іншим традиційним для українського фольклору еквівалентом - означенням красн-; у цьому різновиді фольклорних текстів означення красн- використано зрідка: Чи ти, мила, така красна, чи мені ся здає? (Гнатюк 1905-1907, III, 141; див. також: 116); інколи ці конкурентні означення поєднані в одному мікротексті з розподілом функцій, напр., у тексті - Ти гадаєш, біла дівко, що ти така красна (Ганичі Тячів - К, 107) біла дівка функційно тотожне 'дівчина', а красна має значення 'гарна'; таку саму диференціацію близьких семантично і конотацією одиниць спостерігаємо в контексті: Ой дубинко зелененька, дубинко, дубинко, / Як ти маю заспівати, красна білявинко? (Гнатюк 1905-1907, III, 238).

\section{4.}

Найпоширенішими позиціями вживання *б’і́ла д’íкка в текстах пісень є:

звертання: Чекай, чекай, б’і́ла д’і́вко, та буду т’а брати, / Та йак буде на новы́й гуд зазул'ка кувати (Буштино Тячів - Грицак); Ий бы́вай, біла дівко, та бы́вай та бы́вай, / Та за мене молодого шу́га не забы́вай (Кричово Тячів - Грицак); Та не шуми, буковин- 
ко, та й не розвивайся. / Але не плач, біла дівко, та й не віддавайся (Вел. Бичків Рахів Куняк, 199); нерідко звертання повторено кілька разів або реалізовано варіантами різної структури, які творять ампліфікаційний ряд: Ти, білявко, уроди́сі, ти, білявко, вдайсі, / Аби́ з тебе, біляви́но ніхто не смія́всі (Березови Косів - Негрич 2008, 26; структурно близький варіант в: Солотвина Богородчани - Куняк, 176); Ой біла білявино, а біла білява, / Як же тебе не любити, кой ти кучерява (Заднє Іршава - К, 153); Ой білява білявчино, ой білява білько, / Не мож тя ся налюбити, хоч би-м любив кілько (Волосянка Сколе - Сокілв, 515 ; варіант звертання - Ей біла білявина, а ти біла білька записано в Горінчово Xусm - Грицак);

називання об'єкта поза ситуацією звертання, апелювання: Хвалилася біла дівка межи дівочками, / Що ся буде віддавати з трьома сорочками (Нересниця Тячів - Куняк, 193); А дай мене, моя мамко, за білого хлопия / Аби їму личко цвило, як ружа в городці (Вел. Ключів Коломия - Савчук, 43); Я ше не мав рік штирнаціть, лиш штири неділі, / Та й заводив, брате, в холод молодиці білі (Савчук, 98);

переповідь-цитування: Нема того, що ми казав: «Любко солоденька» (Тужилів Калуши Куняк, 202).

Виразного переважання першого чи другого типу в текстах коломийок не зауважено, а контексти з переповіддю - явище рідкісне.

5.

Еквівалентами загальних назв дівка, молодиия, хлопещь, легінь у таких словосполуках часто $\epsilon$ антропоніми, що спершу могло бути зумовлено апелюванням до реальної особи чи іiі називанням, а згодом перетворилося в усталену фольклорну форму - своєрідний маркер пісень про кохання, напр.: Ой де ти та бувала / та біла Уляно. / 3 учарями за горами, / рудна моя мамо (Бабичі Мукачів - Грицак); Ширі́ночко англ'ійо́ва, йак ми ў то́бі фа́йно. / Богда́й здоро́ў, шчо ми купи́ў бiле́н'кый Миха́ло (Дубове Тячів - Грицак); Як Николу не любити, Никола біленький (Вел. Ключів Коломия - Савчук, 39). Нерідко в пісні поєднано кілька варіантів антропоніма, їх ампліфікування: Ой біленька Марусино, ой біла Марічко, / Я би тебе цілував, хоть би не спав нічку (Сваричів Рожнятин - Куняк 158). Використання антропонімів у карпатських коломийках - явище поширене, а ряди антропонімів розгалужені; здебільшого такі тексти (особливо їх сприймання 3 дистанції часу та просторової перспективи - 3-поза карпатського ареалу) залишають враження називання реального адресата. Заступлення загальних назв антропонімами не впливає на виявлення експресії та загальну конотацію пісні.

Відчутне насичення карпатських коломийок антропонімами на тлі значно рідшого їх використання в текстах тематично близьких українських пісень із регіонів поза Карпатами дозволяє кваліфікувати цю особливість як ареально релевантну рису поетики українського фольклору. 
6.

Коломийки про кохання $є$ відносно усталеним, типізованим змістовим простором із часто передбачуваними суб'єктом повідомлення й об'єктом звертання / апелювання, когнітивним спрямуванням тексту; «фабули», обставини та атрибути відтворюваних «подій» нерідко так само типізовані й прогнозовані. Загальна заданість структурно-змістової архітектоніки пісень цього тематичного циклу уможливила широку синонімізацію, формальне заступлення одних вербальних елементів іншими зі збереженням їхнього загального «змісту» та оцінного спрямування. Для відтворення відповідного змісту та досягнення емоційного стану творці коломийок використовували різноманітні вербальні засоби, співвідносні чи тотожні 3 *біла дівка; ряди таких функційних еквівалентів доволі широкі. Типовими серед них $€$ :

- Похідні від біл- ${ }^{8}$, що часто структурно продовжують сполуки *біла дівка й постали на їх основі, - білявка, біл'авина, білявиця, білька: Ой займила товар пасти білявиия моя (Гвізд Надвірна - Куняк, 135); у багатьох контекстах трапляється по кілька похідних від основи біл-: Ой бі́ла біл'а́вочко, май бі́ла ни бу́деш. / Та дай ли́чко ц’ул’ува́ти, ай так мо́йа бу́деш (Теребля Тячів - Грицак). Унаслідок дії семантико-структурної опозиції постала назва біл'авин, пор.: Йак біл'авка та йе біл'авин (Вонігово Тячів - Грицак). Нерідко автори пісень обігрували деривати від біл-, актуалізуючи обидві семантичні домінанти - «колір» і «позитивна оцінка»: Ой білявко та й білявко, ти білявко біла. / Чи ти в полі не робила, що-с не обгоріла ('не засмагла')? (Івано-Франківськ - Куняк, 154; див. також: К, 51, 106, 107); такі зразки «народного етимологізування» записано в піснях із різних населених пунктів, що засвідчує закономірність їх постання.

- Альтернантами до *біла дівка часто є похідні від основ люб[ити], кох[ати] 3 актуалізованим вихідним узуальним значенням: Хорошого любка маю, хорошої неньки. / Хороше сі потрісає коло музиченьки (Тужилів Калуш - Куняк, 202); Як не прийдеш, любку д’мені, піду до тя сама (Косів. Поляна Рахів - Куняк, 45); Не раз моя вечеронька була на снїданє, / А все тото через тебе, любе закоханє (Волосів Надвірна - Гнатюк 1905-1907, III, 208); Моє миле закоханє, не мож тя забути (Осташівці Зборів - Гнатюк 1905-1907, III, 205).

- Широко репрезентовано похідні від солод-, які в дискурсі української культури, зокрема в піснях, є важливим засобом вербалізації концепту «кохати / кохання»9,

\footnotetext{
${ }^{8}$ Похідні від біл- на позначення дівчини, хлопця відбито в окремих діалектних словниках (без коментування генези та особливостей функціонування), зокрема: у гуц. говірці Березови Косів. біля́вина, біля́вка, гіля́вка 'кохана дівчина' (Негрич 2008, 26); у бойк. гов. - біл 'авина' ‘мила' (про дівчину) і 'милий, коханий' (про хлопця - рідко); як семантично тотожні з біл'авина' наведено біл'аўка, біл'аучча, біл'аўчина, біл'ка (Онишкевич 1984, 1, 56-57); у закарпат. гов. с. Сокирниця (Хустський р-н) зафіксовано біл'авочка 'кохана дівчина' на тлі вживання в поточному мовленні біл'авин 'блондин', біл 'а́вина, біл 'а́вка 'блондинка' (Сабадош 2008, 25), що свідчить про збереження зв’язку з біл- 'білий / світлий’; у гуц. гов. bilawka ‘блондинка' з ремаркою «W pieśni» (Janów 2001, 11).

9 Про семантичну й функційну багатоплановість солод- / слад- (і похідних) та зв’язки 3 концептом «кохати / кохання» в культурному коді слов'ян див.: Седакова 2012; про концепт «солодкий» у традиційній культурі болгар див., зокрема: Седакова 2000.
} 
синонімічним до біл-: Ой бїла біл'а́вочко, соло́ткуй муй меде, / Ба шчо нам с’а c’ого го́ду л’уби́ти не веде (Липча Xусm - Грицак); Ой солодка яблїночка, солодко зродила, ще й солодма дївчинонька попід ню ходила (Ямниця Тисмениия - Гнатюк 1905-1907, III, 6); Ой за річков солодьитко, за річков, за річков. / Не знайшов би таке друге, хоч би шукав свічков (Сваричів Рожнятів - Куняк, 195); Солодьитко повбнімаю та націлуюся, / Та й так смачно спати ляжу, як меду нап'юся (Цупилів Надвірна - Куняк, 197); часто трапляються контексти, у яких конотація солод- посилена поєднанням з мед-: Там то голос, там то мова, там то хід тихенький, біле личко як яблочко, як мід солоденький (Пасічна Надвірна Гнатюк 1905-1907, III, 246); Ой любку мій солоденький, солодкий медочку! (Угорники Коломия - Куняк, 85); Ой Іване, Іванику, Іване білийкий, / Чи ты в медi викупався, що-сь ми солодийкий? (Волосянка Сколе - Сокіл, 520). Синонімізація оцінних полів різних мовних одиниць, накладання метафоричних значень, конотацій солод- і біл- у просторі концепту «кохати / кохання» засвідчена багатьма пісенними контекстами; взаємодія полів зумовлює субституювання елементів, що інколи породжує оказіональні словосполуки, які не трапляються в позафольклорному дискурсі, пор. контекстуальне ототожнення означень біл- і солод- у двох варіантах голосіння в одній говірці (парубок «звертається» до покійної нареченої):

а) ноги мої білюсюнькі, / руки мої білюсюнькі, / очка мої сивесенькі;

б) ручки мої солоденькі, ніжки мої солоденькі, губки мої солоденькі, очки мої солоденькі (Суходіл Рожнятів - Куняк, 333-334).

- Субституювання *біла дівка може стосуватися одного чи обох елементів словосполуки: Люблю тя, рыбко біла, люблю твій позорець, Так ся на тя позираю, як сивий соколиць (Волосянка - Сокіл ${ }^{\mathrm{B}}$ 690); Вийди, рибко солодийка, 3 чорними бровами (Верхня Рожанка Сколе - Сокіл $\left.{ }^{\mathrm{B}}, 508\right)$; використання рибка для називання особи замилування / кохання відповідає традиційному для українського фольклору символічному ототожненню людини 3 позитивно оцінюваними об'єктами природи (ряди таких ототожнень у коломийках див: Лесюк 2010, 14-26).

- Експресію тексту нерідко посилює поєднання кількох первісно самостійних елементів у розгорнутій багатокомпонентній номінації коханої / коханого: Любко моя солоденька! Не сходиш ми $з$ дива (Олієво-Королівка Городенка - Куняк 159); Солодка ма, біла рибко, солодка ма душко (К, 126); Бирвіночку зелененький, стелисі низенько, / Ой, любку мій солоденький, присуньсі близенько. / Бирвіночку зелененький, стелисі ше нижче, / Ой, любку мій солоденький, присуньсі ше ближче (Вел. Ключів Коломия - Савчук, 25); Солодка ма' файна рибко, жаль ми за тобою (Верхня Рожанка Сколе - Сокіл ${ }^{\mathrm{B}}$ 514). Словосполуки рибко солодийка, любку солоденький, моє закоханє тощо належать до клішованих формул карпатських пісень про кохання; деякі 3 наведених номінацій стосуються як дівчини, так і хлопця, пор. у діалогізованому тексті: Прийди, прийди, файний любку, прийди не барисі. / Прийду, прийду, файна любко, прийду, не журисі (Вел. Ключів Коломия - Савчук, 34); інколи номінацію розгорнуто в ампліфікаційний ряд, що об'єднує синонімічні засоби вербалізації відповідного поняття як культурного символу, напр., часто як звертання до коханої особи використано синтагми 
солодкий мій меде, солодкий медочку; у цьому ж ряду - порівняння, епітетизація 3 використанням словосполуки солодкий мед, напр.: Там то голос, там то мова, там то хід тихенький, / Біле личко як яблочко, як мід солоденький (Таурів, Пасічна - Гнатюк, 1905-1907, III, 246).

- Бажаний для автора / виконавця пісні емоційний ефект часто досягається посиленням присутності білого як маркера концепту «кохати / кохання» через зіставлення, порівняння з реаліями білого кольору чи алюзії до таких реалій, пор.: А в Лоп’янці такі дівки, як білий папірещьь (Лоп'янка Рожнятів - Куняк, 58; також с. 55); Ой Іванку, кажи, Йванку, не люби циганку, / Але люби мене, руску, біленьку, як гуску (Угорники Коломия - Куняк, 55); Та там наша бесідочка, там милі словечка, / Щоби-с д’мені виходила, біла, як овечка (Німшин Галич - К, 171); Ой Юрію, Юрієчку, Юрію-кришталю [кришталь = 'чистий', 'світлий'] (Ланчин Надвірна - Куняк, 64).

Посиленню експресії тексту пісні сприяє його насичення спільнокореневими дериватами, напр.: Ей ты, біла білійан'а, ой ты біла білко (Вучкове Міжгір'я Грицак 2017, 225); Ой пішов я до білявки, що білявка діє, / А білявка на припічку білі ніжки гріє (Богдан Рахів - Куняк, 167); Ой ти Йване, білий пане, біле личко твоє, / Біле твоє, біле моє, біленькі вобоє (Костільники - Гнатюк 1905-1907, III, 240); такі самі повтори похідних часто трапляються і від основ, альтернативних до біл-: Казала-м ти, любий любку, лишитися мене (Бедевля Тячів - Куняк, 67).

7.

У фольклорних текстах (зокрема коломийках про кохання) означення біл$€$ елементом багатьох словосполук на позначення різноманітних реалій; такі синтагми трапляються значно частіше порівняно зі структурно подібними складеними номінаціями 3 назвами інших кольорів.

Словосполуки з біл- входять до різних тематичних груп, що уявнюють наведені нижче матеріали, які, проте, не вичерпують репертуару можливих номінацій; зокрема це:

назви людини - біла дівка (дівка біла), б. молодиия, б. жона, б. лялька 'дівчина', б. хлопець 'парубок', 'малий хлопчик', б. молодче (Кл. відм. від молодець), б. + ім’я дівчини, парубка, б. дитя 'дитина (хлопчик)', б. сын, б. пан, б. рід (біленького роду), б. вівчар (вівчарча 'вівчарик'), б. кухарочка 'кухарка (на весіллі)';

н. частин тіла людини (соматизми) - б. тіло, б. ноги (ніжки), б. лице (личко), б. руки (ручки), б. палець (пальиі), б. груди, б. плечі, б. писі 'губи', б. шия, б. стан, б. бік (попід білі боки), б. кості;

н. полотна, сировини для полотна, одягу та його деталей, взуття - б. полотно, б. плат (платина), б. вовна, б. рубатя 'одяг', б. сорочка, б. портки 'штани', б. кожух, б. сіряк, б. хустина (хуститьо), б. рушник, б. рантух (рантушина) 'тонке полотно, яким жінки пов'язували голову; різновид хустки', б. фартушок, б. край (хустки, «ширінки»), б. вельон, б. серпанок, б. онучі (внучі), б. волоки (волічки), б. ремінь; 
н. страв, хліба, виробів із тіста - б. будзь 'овечий сир', б. юшка, б. колачик 'колач'; н. поселень, будівель, приміщень, інтер'єру - б. хата, б. сіни, б. вікна, б. двори, б. мур 'муроване укріплення', б. ворота, б. танки (мн. від танок), б. стеля, б. уличка 'вуличка', б. столик, б. лава, б. постіль, б. перина, б. подушка (подушечки);

н. тварин, птахів та частин ӥхнього тіла - б. худоба, б. товар 'худоба', б. корова, б. воли, б. вівиі, б. стадо (овець), б. вовна, б. лапки (барана), б. ягня, б. баранці (баранята), б. коні / коники, б. грива (коня), б. козонька (коза), б. вленя 'оленя', б. пес (песик), б. пташка, б. лебідь, б. гуска / гуся, б. качка, б. сорока, б. пір'я;

н. рослин та їхніх частин - б. скороздря 'овес ранній', б. гречка, б. просо, б. фасолька, б. косииі 'квіти', б. квітка, б. айстри, б. кіло 'ковила', б. команичка 'конюшина', б. береза, б. калина;

н. об'єктів нежсивӧ природи - б. світ, б. зорі, б. сніг, б. камінь, б. гори, б. труні (труник) 'пагорб', б. півмисок 'заглибина в річці';

н. ужситкових предметів - б. книга, б. папір (папірець), б. лист, б. карта 'картка поштова', б. фана;

н. часових понять - б. зима, б. день (днина);

н. грочових одиниць - б. сороківиі.

Коло наведених синтагм (що може бути удокладнене із залученням до аналізу інших зібрань фольклору) розширюють численні словосполуки з дієсловами з основою біл- (біліє день, білити полотно) та прислівниками (біло ивіте), що відчутно посилює білий складник кольорового розмаїття пісень. Компонент білу пісні нерідко оприявнений кількаразово, що створює своєрідний білий простір - варіативну за складом і позначуваними реаліями динамічну сукупність вербальних елементів; інтегральний для таких мовних елементів складник біл$\epsilon$ основою зближення компонентів їх семантики та конотацій. Окремо взяті словосполуки з означенням біл-, особливо тематично віддалені (як біла дівка і білі ворота, білити полотно і біліють двори, біліє зоря, калина цвіте біло / білим), чи деривати 3 основою біл- видаються семантично слабо пов'язаними чи не пов'язаними між собою. Проте їх оприявнення в просторі порівняно невеликого тексту перетворює розрізнені елементи, співвіднесені з різними (інколи - віддаленими між собою) ідеографічними сферами, в образну й емоційно-оцінну цілість, у якій зростає вага кожного складника. Сформованість білого простору як окремого мовного феномену, усвідомлення його семантичної й оцінної сутності зумовлює поширення означення біл- на інші об'єкти номінації. Наприклад, у контексті - Ой уличко-драбуличко, / Ты, уличко біла, / Та по тоббі, уличино, / хо́дит моя мила (Буштино Тячів - Грицак) - означення біла не зумовлене властивостями десигната, а є, імовірно, наслідком індукції білого простору - реалізацією алюзії до біла дівка як домінанти коломийок про кохання. 3 усталених моделей народнопоетичної синтактики внаслідок фольклорного текстотворення постали й оказіональні номінації з атрибутом біл-, напр.: Ой кухарочка біла, / де-с солонину діла (Ялинкувате Сколе - Сокіл ${ }^{\text {, }}$ 115); Ой заграй ми, гусельничку, білими пальиями, / Най я собі потанцюю з файними хлопцями (Стримба Рахів - Грицак).

Чимало елементів наведеного вище білого простору карпатських коломийок називають реалії, яким притаманна (реальна чи приписувана) кольорова ознака 
білий / світлий; наявність у фольклорних текстах таких словосполук (білий лебідь, білий світ, білий извіт калини, білі руки тощо) відповідає народнопоетичній презентації світу. Водночас у коломийках трапляється багато назв-синтагм, у яких означення біл- не пов'язане 3 кольоровою характеристикою реалії, а використане відповідно до засад фольклорного текстотворення як прийнятний для визначеної мети «будівельний матеріал» (біла вулиця, білий стан [дівчини], білий камінь і под.). Словосполуки з означенням біл-, які повторюються в багатьох пісенних текстах із віддалених між собою населених пунктів, нерідко належать чи тяжіють до народнопоетичних усталених формул, своєрідних кліше. Зауважимо, що чимало словосполук з біл- функціонує і в поточному (профанному) мовленні для вербалізації реалій з відповідними характеристиками за кольоровою ознакою, проте в народних піснях їхнє призначення інше, а підпорядкування іншим засадам добору й функціонування є очевидним.

Нагадаємо, що фольклор як відмінна порівняно зі щоденним (поточним) мовленням форма лінгвального буття соціуму ${ }^{10}$ має низку специфічних рис, серед яких визначальними є виразно творча засада формування тексту творів народної словесності з метою емоційного впливу на реальних / потенційних його реципієнтів, звідси - використання атрибутів театральності мовлення, обігрування форми й змісту / смислів тексту, активне використання асоціативних зв'язків, алюзій, елементів ірреального, міфічного, що разом становить набір можливих засобів творення мовно-образного світу фольклору (див. зокрема: Bartmiński 1990, 12). Якщо в поточній (щоденній) комунікації 3-поміж багатьох складників гору бере прагнення до точного передавання змісту повідомлення, чіткого окреслення іменованих реалій, ознак, дій, для чого мовець актуалізує базову, узуальну семантику слів, словосполук, виразів, то в народній словесній творчості визначальним $\epsilon$ естетизм, вплив на емоції слухача, бажання вразити його незвичними образами, поєднанням слів, асоціативними зв'язками, відповідність виконання / відтворення пісні обставинам, ситуації. Різні передумови породження мовлення (тексту) зумовлюють важливі відмінності синтактики мовних одиниць: поєднання лінгвальних елементів, яке є доречним, бажаним у народній пісні, оцінюване як ії вербальне оздоблення, у позафольклорному мовленні може виявитися стильово маркованим, неузуальним, а то й неприйнятним. Такими, наприклад, є словосполуки з означенням весел- у номінації об'єктів неживої природи у фольклорі: Подивися, мій миленький, подиви, подиви, / Які гори веселенькі, куди ми ходили (Яківка Тлумач - Куняк, 181); Біла любко, біла, як ми ся любили. / Які груні ('гори', 'пагорби') висиленькі, куди ми ходили (Довге Іршава - Грицак); див. також анафору з весел-: звеселіло подвір'я [...], звеселіли вершечки 'гори’ [...], веселі ориниці ‘орані поля’ (Ялинкувате Сколе - Сокіл, 96$)^{11}$, які в ситуації щоденно-

10 Спостереження над фольклорними текстами підтверджують погляд Й.А. Оссовецького, який кваліфікував усну народну словесність як окремий - художній - стиль діалекту: «У мові фольклору [...] на тлі загальнонародної мови наявні у великій кількості такі мовні одиниці, які належать до виражальних засобів мови і які характеризують не розмовне, а емоційно-експресивне мовлення» (Оссовецкий 1958, 177).

11 Широке коло значень похідних від *vesel- у контексті традиційних обрядів, вірувань, фольклору слов'ян подано в: (Толстая 2008). 
го мовлення (без пов'язання 3 народними піснями) у таких контекстах, припускаємо, не використовуються. Сполучення мовних одиниць у народній пісні, що з позиції профанного мовобуття може сприйматися як оказіональне чи нетипове, у контексті канонів фольклорної естетики може виявитися не тільки вмотивованим, а й додатково прагматично навантаженим. Тиск дискурсу нерідко виявляється сильнішим за узуальну семантику слова, його базові зв'язки в лексичній системі мови; тому дискурсивна залежність може виявитися передумовою виокремлення й закріплення за словом нової функції, нових смислів. У зв'язку 3 цим важливими видаються міркування М. Івіч про роль означень у словосполуках бијели врата в сербських і лијепи врата в болгарських піснях, що «служать єдиній меті: підкреслити престижність, яку в контексті поетичної номінації має іменований об'єкт» (Ивић 1999, 11).

У білому просторі карпатських пісень, зокрема в сегменті, співвідносному 3 оцінним характеризуванням об'єктів номінації, проступає модель розвитку семантики *běl-, де, крім вказівки на колір реалій ('білий', 'сивий', ‘синій', 'блакитний’), наявна також їх оцінка, аксіація. Таку двоплановість семантичної структури běl- підкреслюють деривати та словосполуки, зокрема: білозорий, білозористий 'гарний (на вигляд)', білозоря 'красуня', білозоріти, білозорітис'а 'красуватися’ (композити з основами běl- 'гарний’ i zbrěti 'бачити', ймовірно, також *‘мати зовнішній вигляд’); оцінний складник піддається реконструкції на підставі низки похідних, зокрема білан'а 'велика смерека, бук [деревина більша від звичайного розміру, чим особливо цінна]', 'велика колода з хвойного дерева без сучків і кори', біланище 'великий вівчарський ціпок' (Грицак); на тлі виразного домінування позитивної аксіації реалій зрідка за моделлю антонімії в дериватах від біл- розвинулася негативна оцінка, напр.: білкы присл. 'сердито', білолло́ва 'самотня жінка' (Грицак 2017, 226). Позитивна оцінка інколи оприявнена невиразно, проступає як рудиментарний елемент семантики, напр.: біле збіжа 'сорт вівса, що вимагає кращої землі й обробітку' (Онишкевич 1984, I, 56), білий хліб, біла культура 'злакові' [ймовірно, на тлі інших культивованих рослин] (Сбук., $32)$; водночас у багатьох словосполуках біл- сприймається сучасними носіями говірок лише як засіб диференціації реалії в ряду однорідних, без збереження тих імовірних первісних мотивів, які спричинили їх появу як складника номінації, пор. у наддністр.: челядь 'родина' і біла че́лядь 'слуги, наймити', кропива 'звичайна (пекуча) кропива' i бíла кропи́ва 'глуха (непекуча) кропива' (Шило 2008, 52).

Отже, у карпатських коломийках (насамперед про кохання, життя молоді) широко використано словосполуки *біла дівка (та текстові номінативні альтернанти), інші словосполуки з означенням білий та деривати 3 основою біл-. Текстотвірним началом багатьох коломийок $є$ вербальне представлення дівчини / хлопця словосполуками *бiла дівка, яким притаманна нечітко структурована (синкретизована) семантика 'кохана (коханий)', 'гарна (гарний)', 'мила (милий)'. Текстуальне увиразнення лексеми білий у складі назв багатьох реалій (поза називанням дівчини, хлопця) спричинило виформування вторинного оцінного значення, яке у фольклорних текстах переросло в сталий супровід білого простору, який часто цілеспрямовано актуалізовано відповідними контекстами. 
У загальноукраїнському мовно-культурному континуумі поширення словосполуки біла дівка і наявність феномену білого простору ареально релевантне: географія побутування цього явища - діалекти закарпатський, гуцульський, бойківський i лемківський 3 незначними вкрапленнями (iз виразним спаданням частотності використання) у суміжних діалектах; поза окресленим ареалом у тематично однакових / близьких фольклорних текстах використано інші засоби народнопоетичної вербалізації семантики 'кохана [...] мила (особа)'.

Феномен білого простору, його наповнення (структура) актуалізують необхідність з'ясування передумов і напрямів еволюції семантики й синтактики běl-, визначення їх місця в локальних виявах кольорового коду мовнокультурної картини світу українців, а інваріантна модель цього інтертекстуального дискурсивного утворення може слугувати основою зіставних і типологічних студій.

Для виформування широкого карпатського ареалу побутування словосполуки *біла дівка, усталення білого простору як складника поетики народних пісень та чинника трансформації семантичної структури лексеми білий потрібен був тривалий час ${ }^{12}:$ зміни семантики běl- зайшли давно, зумовили постання усталених моделей синтактики, що проступають і в сучасних народних піснях. На давність таких семантичних перетворень опосередковано вказує і те, що окремі деривати з основою біл- та словосполуки з цим означенням як засіб позитивного оцінювання реалій зрідка трапляються в інших архаїчних зонах українського континууму, віддалених від карпатського ареалу, зокрема в підляських, західно- та середньополіських, подільських говірках, де, ймовірно, також є рудиментами архаїки, а не інновацією ${ }^{13}$.

8.

Звертає на себе увагу поширення деяких рис, ідентичних чи типологічно близьких до карпатського феномену *біла дівка, у мовно-культурних традиціях південних слов'ян, аналіз яких може виявитися релевантним для глибшого пізнання складного мовного і культурного простору як Карпат, так і слов'янського макроконтинууму в цілому. Зауважимо, що дослідження рис українських карпатських діалектів / культури нерідко переростало в широку проблематику карпато-балканістики, сприяючи виявленню нових спільних структурних елементів, явищ, поширених у карпатській і південнослов'янській макрозонах. Чимало карпато-балканських спільних мовних одиниць, явищ відтворено на картах загальнокарпатського

12 У зв'язку 3 цим оцінка коломийок як давнього різновиду українських пісень (таку позицію обстоювали В. Гнатюк, І. Франко, М. Возняк, Ф. Колесса, Г. Нудьга), а також окреслення XVI-XVII ст. як періоду розпросторення цього явища словесної культури (див.: Шумада 1969, 31-33; УФЕ I, 388-389), видаються прийнятними.

13 У західнополіській весільній пісні зафіксовано прослідки білий з позитивною конотацією в словосполуці го́стон'к'i біле́н'к'i ‘дорогі, високоповажні гості'; див. також описову номінацію свята Водохреща: Біла Коляда [...] на білому коні (СЗПГ, 22); не зовсім очевидною є мотивація б'ілка 'породілля, яка до трьох місяців не повинна була виходити з хати’ (Холопичі Локачин - СЗПГ, 22). 
і загальнослов'янського мовних атласів, засвідчено в численних нових діалектних лексиконах; лінгвістичну сутність багатьох елементів різних структурних рівнів, їх географію та генезу подано в спеціальних дослідженнях (зокрема в: Бернштейн 1948; Панькевич 1955; Німчук 1988, 1993, 2003; Siatkowski 2001; Клепикова 2002, 2006; Гриценко 2008, 2009 та ін.). Виявлені спільні для українських і південнослов'янських діалектів риси оцінюють або як релікти праслов'янської спільної спадщини, або як результат пізнішого розвитку генетично спільної лінгвальної основи в умовах функціонування окремих ідіомів, або як наслідок тісних усномовних контактів українців зі слов'янами Балкан, зокрема з болгарами й сербами. Такі контакти були жвавими, різносторонніми, відбувалися насамперед на теренах сучасної Румунії та південно-західної частини українського етномовного континууму, зокрема й за умов адміністративно-державного інтегрування цих народів у складі різних держав, спиралися на близьку своїми ознаками господарську діяльність, що незмінно супроводжувалося усною різномовною комунікацією 3 відчутним взаємопристосуванням, інтерференцією, виформуванням спільних лінгвальних елементів, а також перейманням елементів мови, зразків побутової та пісенної культури. Закономірно, що староукраїнські писемні пам'ятки ділового стилю 3 південнокарпатських теренів, що збереглися від XIV ст. (т. зв. молдавські грамоти), відтворюють не лише українську книжно-писемну традицію та тогочасні локальні риси української мови, а й численні наслідки південнослов'янських впливів, спільні для цих ідіомів елементи різної генези.

Для з'ясування особливостей розвитку семантики běl- в українськокарпатському просторі, зокрема і феномену *біла дівка як одного з індикаторів цих процесів, спробуємо виявити визначальні ознаки південнослов'янського тла цього явища, спираючись у своїх спостереженнях передусім на фольклор - болгарські, македонські й сербські пісні. На необхідність перехресного прочитання народних пісень різних слов'янських народів, їх зіставного аналізу віддавна звертали увагу дослідники поетики, мови слов'янського фольклору (див. зокрема: Богатырев 1958; Поповић 2001). I хоча в таких зіставних дослідженнях не завжди доходить до вичерпного розв'язання окреслених проблем (оскільки доводиться спиратися на матеріали різної повноти і якості, не в усьому зіставні, а також ураховувати ексклюзивність фольклорних традицій та залежність останніх від позалінгвальних умов), усе ж виявлення спільних і відмінних рис фольклорних текстів, а $з$ ними - і культурних традицій, зберігає актуальність.

\section{9.}

У болгарських народних піснях лексема бел (бял) репрезентована широко, вербалізує не лише значення 'білий, подібний до білого, сивий, протилежний до чорного', а й 'гарний, красивий, позитивний; протилежний до негарний, поганий'; виокремлення цих семантичних домінант має неоказіональний характер, віддавна як узуальне закріплене авторитетними лексиконами (Геров I, 98); тому загальновідомою є синонімія бел і хубав 'гарний'. 
У семантичній структурі лексеми бел значення 'гарний, красивий' (з варіюванням відтінків значень для передавання позитивної оцінки названих реалій) постали передусім із традицій народної пісенної творчості; окремі усталені словосполуки (бъль камыкъ, бъль Дунав, бъли грошеви) лексикографи виділяють як окремі елементи в цьому семантичному полі. Роль фольклору в оформленні значення 'гарний, красивий' у лексемі бел як узуального підкреслюють дослідники болгарської народної словесності, зазначаючи: «Для народного співака бели є: Дунав, църква, книга, лице, образи, пиеница, чадър, кадъна, лоза, ръка, чешма та ін.»; і далі - «Дунав пізнаваний за постійним епітетом бял чи зрідка син» (Иванов $1959,84)^{14}$. Що синтагми з бел у піснях є усталеними, клішованими, засвідчує, зокрема, розподіл частоти вживання словосполук з означенням бел й альтернативних номінацій; напр., при іменнику пшеница у РП із 25 контекстів у 20 зафіксовано словосполуку бела (бяла) пшеница (пченица), 1 - старозагорска n., 1 - зимна n., 3 - пшеница без означення; така сама тенденція відтворена і в СрРП: із 25 випадків зафіксовано 21 - бела (бяла) пшенища (із розширенням другим означенням хилбетска бела пшеница - 6, едринска б. п. - 2, пазарска б. п. - 1), старозагорска $n .-1$, летна $n$. - 1, без означення - у 2 контекстах ${ }^{15}$. Таку саму тенденцію використання варіантів словосполук 3 означенням бел демонструють назви багатьох часто згадуваних у піснях реалій, що підтверджує обгрунтованість оцінки бел як важливої пізнаваної риси поетики болгарського фольклору. Цю особливість зауважили й мовознавці, підкресливши: «Часто народні співаки використовують бял для позитивної характеристики свого героя, який завжди є ідеалом краси. Дівчата завжди бели-червени, с бели нози, бели ръце, с бели дрехи, с бели зъби» (Коспартова 1972, 82). Тому закономірним є широке використання у болг. піснях бел (бял) у складі двокомпонентних назв дівчини, молодої жінки: у таких номінаціях бел передає значення 'гарна', 'мила' та загальну позитивну конотацію ширшого контексту, напр.: Най-отзад иде, мале ле, чичова Кула Драгула, / чичово бело момиче (БНТ, 203).

Таке використання словосполуки бела (бяла) мома 'гарна дівчина' у болг. піснях має надійні відповідники в українськокарпатській традиції; водночас болг. бела мома виявляє чимало специфічних структурних і функціональних рис порівняно з укр. *біла дівка, напр.: називання хлопця, чоловіка словосполуками з белу болг. фольклорі зафіксовано в поодиноких випадках (напр., у родопській пісні записано планинско бяло юначе - РП, 231).

Типологічно тотожним для укр. і болг. традицій є використання словосполук běl- + ‘дівчина' в позиції звертання до названої особи та поза позицією

14 Зауважимо, що зрідка означення бел зафіксовано і в поєднанні 3 іншими гідронімами (бели Bapдар - БНТ, 109) та загальною назвою река (бяла река широка; край бела речка - РП, 250, 592 та ін.), що загалом не підважує народнопоетичної символьності сполуки бел Дунав.

15 У болг. піснях бела пшеница нерідко є символічним позначенням молодої дівчини на виданні на противагу образу скошеної недостиглою (ще зеленою) пшениці, що символізує передчасно віддану заміж дівчину, пор.: - Ки́тена бела (n)ченѝцее, / Много ми беше у́бава, / Доде ми беше на ни́ва. / - А про́клет да е баща̀ ми, / Навика̀ си аргакье - / Зеле́но ме ожна̀а, / Сурово ме върша́а, / Доне́соа ма на гу́мно, / Много скоро огрознех (Гюешево Кюстендилско; варіант записано в Долно село Кюстендилско - ЗП, 161). 
апелювання до неї. Так само ідентичними українській традиції є моделі заступлення: замість мома, момиче, девойка 'дівчина' часто як еквіваленти використано бу́ла, кадъна, які найчастіше передають значення 'молода заміжня жінка', 'молода заміжня туркеня', а в поєднанні з бел відтворюють виразні позитивні конотації, напр.: бела була (ЗП, 109, 110, 123); бяла кадоно (БНТ, 372, 443); Хайшенко, бела кадъно (РП, 577; також: 345); примітно, що кадъна як позначення еталону дівочої краси, досконалості часто є компонентом порівняльних конструкцій: Стуйено, моя дощерьо, / бела бя кату кадона, / червена кату йебълка [Стояно, доню моя, ти біла як кадона, червона як яблуко] (РП, 230; також: 203, 368, 825, 826; СрРП, 404, 459); такий розвиток семантики кадъна зумовив постання деривата кадънджийка 'дівчина / жінка красива як кадъна' (ПК I, 948).

Інша типова для болг. пісень модель називання дівчини - використання замість мома власного імені: Бяла Станка дваж по-бяла / дваж по-бяла от цветото / триж червена от чумберя (БНТ, 72; також: 107, 387, 404, 424 та ін.); Радо, бяла Радо (Кауфман 1982, II, 418); Гроздена, бела Гроздена (П3, 105); убава бела Станка (ПЗ, 115); бел Димитра руса коса (РП, 39). Зіставне прочитання болг. і укр. пісень про кохання залишає враження, що болгарській традиції порівняно 3 українською притаманне більше насичення текстів антропонімами, ряди яких розмаїтіші; окремі імена є часто повторюваними, трапляються в записах пісень iз різних регіонів (жін. імена Рада, Неда, чол. - Стоян), що може свідчити про клішованість таких фрагментів тексту. Зауважимо, що сполуки бел- (бял-) + антропонім у болгарському континуумі, ймовірно, доволі широко функціонували й за межами фольклорного дискурсу, репрезентували й іменування чоловіків, що засвідчує творення прізвищ. Саме з таких словосполук постали, на думку дослідників, прізвища Бѐлдимйтров - < белия Димитьр, Бѐлдимов $-<$ белия Димо, Белинѐев < бели Нейо; у такий самий спосіб пояснено виникнення прізвищ Белива̀нов, Бя̀ливанов, Белко̀лев, Белма̀рков, Бя̀лмарков, Белнико̀лов, Бѐлстойнев і под. (Илчев 1969, 69-70, 98). Промовистим є коментар Ст. Ілчева до чол. імені Бѐльо «от бел, бял в смисъл 'хубав', 'здрав'» (Илчев 1969, 71), що вказує на давню сформованість для бел (бял) вторинного значення 'красивий (хубав)' і постання на цій основі нової оцінної семи 'здоровий (здрав)'. На уявлення про те, що доля дитини залежить від наданого їй при народженні / хрещенні імені, вказують болг. антропоніми $з$ основами, пов'язаними 3 позитивною конотацією, зокрема жін. імена Бя̀ла, Бя̀лка, Здра̀вка («от прилаг. здра̀ва - пожелателно име за здраве»), чол. і жін. імена з основою хуб- (Хуба̀н, Хуба̀на, Хуббака, Хубавйца) (Илчев 1969, 98-99, 212, 523-524) тощо.

У піснях із різних регіонів Болгарії трапляються словосполуки бел- + етнонім, що відомо і в карпатських піснях ${ }^{16}$, де такі номінації зафіксовано значно рідше порівняно $з$ болгарською традицією. У болг. фольклорі найчастіше оприявнена синтагма бела българка, що, зокрема, використовується в багатьох варіантах пісні з відомим сюжетом про вибір нареченої з-поміж представниць різних народів, де

\footnotetext{
${ }^{16}$ Пор. укр.: На високій полонині гуцулочка біла, / На високій полонині корівки доїла (Сваричів Рожнятів - Куняк, 82); у цьому ряду - бойчиха, мазурка, також бойко, лях (докладніше в: Лесюк 2010, 18).
} 
першість зазвичай віддавано болгарці, пор.: Стояне, синко Стояне, земи си бела българка (БНТ, 65); див. також: Досега си бяла българка (Кауфман 1982, II, 380); българка [...] бела, червена (ЗП, 255). Сполуки бела българка нерідко оприявнена як елемент формули звертання в зачинах пісень та в повторах-рефренах (нерідко - багаторазових упродовж пісні): Кальо, бяла българко (СИБ, 577); Златица бе́ла бо́лгарке (СрРП, 161; також: 255, 267, 355 тощо). Значно рідше зафіксовано словосполуку бела гъркиня, напр., у піснях болгар в Україні: бяла гъркиня хубава, / тъй си бе сладко заспала (Ореховка Болград - Кауфман 1982, I, 197; див. також: РП, 891; СрРП 312). Зауважимо, що в часто вживаній синтагмі бела кадъна етнічна ідентифікація проступає не завжди виразно, імпліковано, оскільки для виконавців пісень кадона / кадъна може мати значення 'наречена', 'молода невістка', 'молода дружина', 'дружина магометанина', 'магометанка' (СрРП, 531; див. також: РБЕ 7, 33-34). За цією моделлю утворено словосполуки на позначення гарного хлопця: излеิзе берло болгарче (СрРП, 362); аз имам бяло българче (НПК, 307). Зазначимо, що синтагми моделі бел + назва хлопия в болг. піснях поодинокі ${ }^{17}$, що контрастує із широким представленням у карпатських коломийках номінацій бiлий хлопеиь / легінь. Спорадично трапляються контексти із синтагмою бели гърцุu: ни идат ли турци за вино / и бели гърции за жито (Кауфман 1982, II, 371); зрідка бел є складником назв мешканців визначеного населеного пункту, напр.: овчари, бели котлянци [від назви міста Котел] (НПК, 266), що, ймовірно, є проявом номінативної індукції означення бел у фольклорних текстах.

Іншим пізнаваним елементом поетики фольклору й мовної картини світу болгар є двокомпонентне означення бело червено при означуваному - номінації дівчини (варіанти бело и червено, бело-червено відтворюють різні етапи універбізаціiі), часте використання якого значно розширює оприявнення бел- у народних піснях, напр.:

Девойче бело, червено, не оди ситно пред мене, не задавай ми ядове (БНТ, 393; варіант пісні із Кюстендилско зі збереженням наведеної формули див. у: П3, 30); Я дайте си ми, дено си галям, / дено си галям беличко Раде, / беличко Раде, бело, червено, / бело, червено по двори ходи, / по двори ходи и метла мете (Бачково Асеновградско - РП, 358); и на Иван дял падна / идна му тенка дивойка, / тънка, тънка, висока, / висока, бяла, чървена (Кауфман 1982, I, 640); див. також: Ленче, бре Ленче хубаво! Бреш то си толко хубаво, хубаво, бело, иървено (БНТ, 84); Девойче бело, иървено (ПЗ, 30).

У багатьох контекстах засвідчено розвиток цієї словосполуки за моделлю синонімічного заступлення в межах назв кольорів одного хроматичного сегмента, пор.: Беличко, бяло румяно (Кауфман 1982, II, 618), по идна тънка дивойка, / тънка, тънка, висока, / бяла, бяла, румяна (Кауфман 1982, I, 640); Димано бело румено (П3, 85). Поєднання в комплексній назві бело червено хроматично

17 У цьому ряду номінацій і словосполука бело копеле: Хасане, бело копеле, / двечера имам межица, / межица и попрельчица [Хасане, гарний парубче, увечері будуть вечорниці, вечорниці й попрядки] (РП, 283), яка засвідчує нейтралізацію негативної конотації копил- 'позашлюбна [дитина]', що проступає в багатьох дериватах (РБЕ 8, 12-13). 
віддалених кольорів - наслідок давньої атракції оцінних мікрополів кольороназв ${ }^{18}$, а не їхніх базових значень; таке зближення функцій різних кольорів оприявнене також у спільному використанні реалій білого і червоного кольорів як оберегів (Белова 1995, 650). Структурно поширене означення, що сягає назв білого і червоного кольорів, у піснях зрідка стосується реалій, які є поетично-міфологічним субститутом дівчини (найчастіше - це яблуко, квітка).

Зближення, синонімізацію конотативних полів етимологічно не споріднених номінативних одиниць - унаслідок контамінування словосполук, близьких за оцінкою позначуваних десигнатів чи доєднання до базової сполуки нового інтенсифікатора позитивної характеристики - зумовило постання нових структурно ускладнених синтагм, зокрема часто повторюваних у піснях словосполук момиче бело чернооко, пор.: бело чернооко (черноко) момиче (РП, 121, 122, 349, 398, 462); момиче бело, черночко (РП, 583); момиче бело, черноко, черноко (РП, 145; також: СрРП, 299); у поодиноких випадках таке розширене означення стосується хлопця: бело-черноко ко̀пеле (СрРП, 500).

Номінація бела мома входить до кола функційно тотожних словосполук, серед яких у текстах часто трапляються утворення з означенням хубава [мома] (найчастіше), рідше - гиздава ('гарна, красива, ошатна, чепурна'), лична ('видна, знана, помітна'), млада, напр.: Маринчице, гиздава девойко, / Леко пееш, далеком се чуваш (СИБ, 244); нерідко в синтагмі чи невеликому тексті поєднується кілька означень: Ой ти моме хубаво и лично (БНТ, 410); Девойко мари хубава, / девойко мари гиздава (БНТ, 75).

Тексти багатьох пісень насичені словосполуками з означенням бел та дериватами від цієї основи, що посилюють приявність білого простору, употужнюють його символьність; останнє зумовлює індукування конотацій бел, розширення кола реалій, названих словосполуками із цим означенням. Пісні, у яких використано кілька елементів із бел, трапляються доволі часто в записах фольклору з різних регіонів Болгарії та діаспори, напр.:

бе̂ло шуменско момиче / На мермѐр камень седе̂ше, / бе̂ло си лѝце мие̂ше, / с бе̂л го пешкир бришеิше [Гарна шуменська дівчино, на мармуровому камені сидиш, біле личко вмиваєш, білим рушником втираєш] (Чепеларе Смолянско - СрРП, 256; варіанти цієї пісенної формули наведено також в: РП, 421); Бели мома тънки дари, / набяли ги, напростря ги / край калдърьм бял Дунава, / чи си стъпна на бял камън, / та си юми бяло лици, / бяло лици лебедьово, / черни очи чирешови [Вибілює дівчина тонкі полотна, вибілює і розстеляє їх край кам'яного берега білого Дунаю; умиває біле обличчя, біле обличчя лебедине, чорні, як черешні, очі] (Андровка Бердянськ Україна - Кауфман 1982, I, 525); Стано, Стано юбава, / на бял Дунав ютишла, / бяло лици миеши. / Колкото го миеши, / дваж по-бяло ста́ваши. / [....] Язи имам, Стане ле, / Тънка бяла мъйръмъ, / в мъйръмътъ вързану / два сребърни пръстена [Стано, мила Стано, на білий Дунай прийшла, біле обличчя вмиваєш. Стільки його вмиваєш, вдвічі білішим воно

18 Структури полів назв, що первісно позначали білий і червоний кольори, у їхніх оцінних сегментах виявилися близькими, функційно пов'язаними не лише в болгарській, а і в інших слов'янських традиціях, зокрема в сербській (Ивић 2001; Поповић 2001), російській (Вендина 2000; Толстая 2008). 
стає. Візьми, Стано, білу хустинку, у яку загорнуто два срібні перстені] (Нові Трояни Болград Україна - Кауфман 1982, I, 220).

Коло реалій, які в болг. піснях вербалізовані словосполуками з означенням бел-, дуже широке; спостереження засвідчують, що в зібраннях пісень 3 різних регіонів Болгарії та місць переселення в Україні й Молдові білий простір оприявнено варіативно як щодо кола названих реалій, так і засобів їх мовного презентування, що корелює 3 діалектною диференціацією континууму; тому в болг. просторі зафіксовано альтернативні відповідники-словосполуки на позначення однієї реалії (див. нижче, зокрема назви одягу, різновидів хліба тощо).

Білий простір болг. фольклору засвідчує чимало рис, спільних із піснями карпатського регіону, зокрема стосовно реєстру названих об’єктів; такі відповідники утворюють ізоглоси, з'ясування природи яких становить предмет спеціального аналізу. Це словосполуки на позначення як реалій білого (світлого) кольору, так і з природи не-білих об'єктів чи для яких ознака за кольором не релевантна, а використання означення бел (і похідних від цієї основи) підпорядковане традиціям творення фольклорного тексту; зокрема, це:

назви людини - бела мома 'дівчина', б. момиче 'мала дівчинка', бела (белинко, белич$\kappa о)+$ ім'я дівчини (Рада, Неда, Станка, Дона), б. кадъेне 'молода невістка', 'наречена', 'молода дружина магометанина', 'туркеня', б. була 'молода туркеня', б. ханъмка 'туркеня’, б. кокона 'пані, чепуруха', б. българка, б. гъркинz, б. помакиня 'болгарка-мусульманка', б. копеле 'парубок', б. булгарче 'болгарин-парубок', б. гражданин 'міщанин', б. гражданка 'міщанка'; також белинко, беличко 'дівчино' (у звертанні); зрідка бел $\epsilon$ складником назви мешканців визначеного населеного пункту (як б. котлянии);

н. частин тіла людини (соматизми) - б. лице, б. бузки 'щоки', б. руки, б. ноги / б. крака 'ноги', б. гърло, б. шийка 'шия', б. брада, б. рамена 'плечі', б. пазухи (пазви, пазушки) 'жіночі груди' і ‘пазуха в жіночому одязі'; близьке до соматизмів б. nom 'піт' (ситен бял пот 'дрібний піт [на обличчі коханого]');

н. надприродних істот - божи бели ангели;

н. полотна, сировини для виготовлення полотна, одягу, його деталей, взуття б. платно, б. дари (дарове) 'вироби з полотна - подарунки на весілля', б. пране 'речі для прання', б. руба 'одяг', б. дрехи 'одяг', б. премена 'одяг; святковий одяг', б. фуста 'нижня спідниця', б. фустан 'верхній жіночий одяг', б. фути 'фартух з грубого полотна', б. гиздило 'прикраса; святковий одяг', б. прекровка 'жіночий одяг', б. покров 'біле полотно для покривання тіла мерця', б. кърпа (мн. б. кръпи) 'рушник; хустка', б. мъйръмъ 'хустка (хустинка) з китицями', б. дюльбенче 'хустка', б. превез 'тонка тканина, якою закривали обличчя нареченої’, б. тестемел 'тонка хустка, рушник', б. мангоре 'жіноча накидка поверх хустки зі срібними прикрасами', б. було 'фата, вельон нареченої’, б. риза (ризииа) 'сорочка', б. кошуле 'сорочка', б. фанела 'майка', б. рокла (рокля) 'сукня', б. пешкир 'рушник', б. сая (б. сешща) 'білий довгий верхній одяг, який носили дівчата', б. ялек (ялеци) 'безрукавка', б. ръкави (ракаве) 'рукава', б. кепе 'берет’, б. хавлия 'скатертина', б. халище 'товста вовняна тканина для застилання', б. юргани 'стьобана ковдра', б. налима 'шовк; шовкова тканина', б. коприна 'шовк', б. памук 'бавовняні нитки', б. ямурлук 'верхній вовняний одяг, бурка', б. япунджак 'верхній одяг від 
дощу', б. журапи (чорапи) 'панчохи; товсті в'язані шкарпетки', б. калчини 'товсті шкарпетки', б. чехли 'пантофлі', б. убувки 'взуття';

н. страв, хліба, виробів із тіста - б. месо 'м'ясо', б. млеко, б. ориз 'рис', б. брашно, б. пога́ча 'різновид хліба', б. пита 'круглий пшеничний хліб', б. ба́ница 'листковий пиріг', б. бревенищи (у с. Горни Коритен Кюстендилско пояснено як баница), б. кравае ‘коровай', б. плетеница 'різновид булочки', б. симид (симиче, семиде) ‘булочка' (зауважимо: назви виробів $з$ тіста в болг. піснях трапляються доволі часто, переважно у формі словосполуки з означенням бел; натомість в укр. піснях Карпат такі контексти трапляються рідко, а згадуваний у весільних піснях коровай має означення красний);

н. напоїв - б. ракия (інколи - із розширенням означення: бяла бистра 'чиста' ракия); н. поселень, будівель, приміщень, інтер'єру - б. град, б. двор, б. манастир, б. колнак, б. коначе 'приміщення, де ночують подорожні', 'нічліг', 'добре упорядкована кімната', б. дукяна 'приміщення для торгівлі', б. врата 'двері; ворота', б. прозореи і б. пенжер 'вікно', б. чадъра 'намет';

н. тварин, птахів, риб та ӥхніх частин тіла - б. ата 'жеребець, огир', б. волове, б. агне 'ягня', б. лебеди, б. гъльби 'голуби', б. гуска, б. летници 'форель';

н. рослин та ӥхніх частин - б. пчени́иа, б. жетва 'жниво (не скошене)', б. лозе 'виноград’, б. грозде 'грона винограду', б. гюл і б. трендафил 'троянда', б. ружа, б. кокиче ‘підсніжники', б. босилек 'васильок', б. пелин 'полин’, б. бели́а ‘сорт білої пшениці', б. китки 'букет квітів', б. кумунига 'буркун';

н. об'єктів неживої природи, географічних об'єктів - б. Дунав, б. Вардар, б. камък, б. варове 'вапно', б. вятер, б. снег;

назви ужситкових предметів - б. книга (кинига) 'книга; папір (для писання)', б. тефтере 'книга для записування, нотування', б. кемери 'шкіряний гаманець, що носять на поясі', б. менции 'мідні казани - посудини на коромислі для носіння води', б. бакъре 'посудина (носити, тримати воду)', б. харкома, аркуми / б. котле 'котел; посудина для носіння води', б. сарчьо̀џе ткацьке начиння - залізна вісь у снівниці', б. чиния 'тарілка, блюдо', б. остен 'палиця поганяти воли', б. ветрила 'вітрила';

н. часових понять - б. събота 'субота перед Великоднем';

н. грошових одиниць - б. громе(о)ве, б. пари, б. рупове (руп 'монета'), бели леви [за коня дават бели левови - БНТ, 89] 'плата, гроші', б. меджедия 'срібні монети епохи Абдул-Меджида', б. петолевки 'асигнації в п’ять левів'.

Звертає на себе увагу не лише широке коло реалій, названих словосполуками з бел-, а й прийоми їх використання в текстах, досягнення з їх допомогою виразної конотації. Це не лише добір сюжетів пісень, реалізація яких передбачає звернення до таких синтагм, а й прийоми конструювання тексту. Так, у піснях із різних регіонів одним із часто описуваних занять дівчат, молодих жінок є вибілювання полотна, прання на річці полотняних виробів; особливістю вербалізації таких сцен є насичення контекстів кількома дериватами від бел-, що актуалізує й посилює білий простір, напр.: беело да пѐрам, пла̀тно да берлем (СрРП, 219); ти бела кушуля на бел Дунав белена (БНТ, 116; див. також: ЗП, 271); інша «жіноча» тема, що так само часто оприявнена в піснях, стосується придбання / використання косметичних засобів, насамперед белила і червила (на бело лице беิлило - СрРП, 222). 
Для посилення концепту «білий» (у його зв'язках із концептом «гарний, позитивний») результативним виявилося повторення в тексті пісні словосполук з означенням бел; зауважимо, що повтори сегментів тексту різної величини належать до універсальних прийомів текстобудови народних пісень, їхньої поетики. Зокрема, нерідко використано повторення зачину кожного рядка-такту пісні, як, напр., анафоричне звертання у весільній пісні: Беле́ ру́ке, што сте работи́ле, / Беле руке, пога́че месиле, / Беле руке, мому отплита́ле, / Беле руке, си́то рассева́ле, / Беле руке, квась́ц рассеца́ле (Драгоман Годечко - ЗП, 137); типовим для структури пісенного тексту $є$ кількаразове повторення окремих тактів: Българските моми (повторено тричі) / Бели кърпи носят, / Бели кърпи носят (тричі), / Гръкчето не жалят (Яворница Петричко - ПК I, 151). Серед засобів творення яскравих образів пісні часто використано гіперболу; словосполука бела мома в тексті з виразною гіперболою зазнає посилення позитивної конотації означення бел; напр., у піснях часто трапляється сюжет, у якому красу дівчини описано як яскравішу за сонце: Не бѝло еิсно слоิнчице, / ам бѝло бе̂ло момиче. / С бе̂ли ми рокки махаше, / с чьорни ми оेчи мигаше [То не було ясне сонце, а була гарна дівчина. Білими руками махає, чорними очима моргає] (Върбина Смолянско - СрРП, 271; варіанти цієї формули див.: РП, 421). Повтори словосполук з бел у просторі пісні посилюють символьність білого простору та концептуального ототожнення «білий» i «гарний / позитивний»; цьому ж процесу підпорядковане і використання багатьох дериватів від bèl- (белолика, белко 'чисто'; триж по-бело 'втричі біліше’; чие е лиць най-бело 'чиє обличчя найбіліше'; круша бялоцвятка 'груша в білому цвітінні' тощо).

Як і в карпатському фольклорі, у болгарських піснях багато контекстів не уможливлюють однозначного розв'язання питання: чи означення бел зберегло зв'язок із семантикою 'білий колір', чи вже втратило; в одних контекстах вказівка на білий колір позначуваних реалій є безсумнівною; в інших - чітко проступає віднесення до поетичної символіки; трапляються контексти, у яких означення бел- суперечить характеристиці названого об'єкта (як белли ха̀ркоми, бели бакъре 'різновиди посуду (здебільшого - мідного), у якому носять, тримають воду').

Спостереження над українськими (передусім регіону Карпат) і болгарськими народними піснями, зокрема з увагою до феномену *біла дівка, засвідчило наявність типологічно спільних / близьких ознак, зокрема щодо ролі формальних і семантичних дериватів від основи bel- у народнопоетичних картинах світу українців і болгар: укр. *біла дівка і болг. *бела мома творять центри широкого білого простору, взаємодіючи з його елементами. Спільним виявилося ототожнення / зближення семантичних полів 'білий’ і 'гарний / приємний / коханий’; типологічно однаковими, інколи - і формально близькими чи тотожними $є$ способи досягнення оцінних конотацій та відчутної експресії пісенних текстів. Водночас чимало елементів семантичної структури běl-, архітектоніки й поетики білого nростору належать до ексклюзивних, зумовлених не лише лексикою пісень (що закономірно з огляду на лінгвальний феномен кожної народної культури, розмаїтість і багатство діалектів), а й структурою культурних парадигм - реєстрами визначальних образів пісень, взаємозв'язками цих образів, частотністю використання в піснях маркерів культурної семантики. Зауважимо, що в болг. піснях 
різних регіонів високочастотним є поєднання *бел- 3 власним ім'ям дівчини (молодої жінки), з назвами Дунав, пшеница, руки, камък, дари, ракия; водночас багато синтагм з означенням *бел- у текстах пісень трапляються зрідка, розширюючи й урізноманітнюючи білий простір; в укр. коломийках висока частотність використання словосполук з означенням біл- притаманна насамперед номінаціям біла дівка, б. хлопець, білий + антропонім, а також соматизмам.

Зіставлення української й болгарської фольклорних традицій в окресленому сегменті - *біла дівка на тлі білого простору - спонукає до поширення спостережень у південнослов'янському ареалі насамперед на просторово суміжні з болгарським - македонський і сербський континууми.

10.

У македонських пісняx використання словосполук з означенням бел відбивають численні контексти; семантика бел стосується як базового сегмента 'білий', 'світлий', так і багатьох вторинних значень - 'ясний', 'спокійний', 'щасливий' тощо, засвідчуючи поєднання традиційного побутового (профанного) мовлення i народно-поетичного (міфологічного). Поетичний складник семантики бел надається на створення позитивної конотації в номінації дівчини як об'єкта замилування, кохання. Тому закономірне називання дівчини чи звертання до неї з використанням словосполуки бел + девојка: Де́војче бе́ло, кра́товче, / не гле́дај го́ре на до́ле (Кратово - ММФ, 361). Проте за частотою оприявнення в текстах пісень такі словосполуки відчутно поступаються іншим моделям називання / звертання, насамперед із долученням антропоніма чи заступленням власною назвою загальної: Шо бело переш бела Марије, / шо бело периш да црно носиш (Воденско МПВ, 160-161); убовата мома Бона, бела Бона (Кукушко - МПК, 179); углавена ('заручена') бела Вела (Горноиумајско - Стоилов 1990, 53); Мариче, бело девојче, / што кротко ткаеш и плачиш (ЉНП, 223); зрідка реалізовано модель бел + етнонім (бели македонки - ММФ, 462; бели гъркине - ПК I, 419; у піснях із Піринської Македонії засвідчено також бела българке - ПК I, 92, 830 та бело българче - ПК I, 838), які оприявнені в багатьох болг. піснях із різних регіонів.

У макед. піснях ряд синонімів до бел як означення до девојка (мома) виявився широким; у ньому об’єднано лексеми, різні за етимологією, ареальними параметрами та частотою використання. Наприклад, лише в одному джерелі - ММФ засвідчено: убава (јубава) 'гарна', мила, милна 'чарівна', драга, мала, малечко, лична 'гарна, видна', либа 'люба', љубчица, добра, севда 'кохана', лепа, гиздава 'гарна, струнка', галена 'ласкава, ніжна', дилбер 'гарна' (невідмінюване), ластар 'тонка, струнка', ѓуззел 'гарна, видна' (у різних діалектах відтінки семантики варіюються). Нерідко кілька означень використано у просторі однієї пісні, де вони творять барокові словесні інкрустації, насичуючи текст епітетами-синонімами: ди́лбер бе́ла Ма́гдено, мо́ме мори (Битола - ММФ, 310); девојчице, драга љубчиизе (ЉНП, 79); девојче, девојче, мило та убаво (ЉНП, 137), милој маличко, / севде ('кохана') убавечко (Кукушко - МПК, 19). У таких ампліфікованих рядах 
атрибутів похідні від бел- використано зрідка. Водночас ця лексема наявна в часто використовуваних клішованих словосполуках бело ирвено, бела румено, що $€$ спільною рисою і для болг. фольклорної традиції (див. вище): Де́војче бе́ло, uр́вено, / ср́мен си елек о́блекло, / ли́бето си че́кало [Дівчина-красуня вдягла сріблом розшиту безрукавку, коханого свого чекала] (Скопје - ММФ, 370); пор. також: Та́м си на́јде ма́лкај мо́ма / та́нка висо́ка, / бе́ла руме́на (Гевгелиско - ММФ, 343); Шти́пските мо́ми бе́ли црве́ни, / бе́ли црве́ни ско́пски јабълки (ММФ, 463); Сега съм една залюбиле, / на лице бела-червена, / на очи черни череши (ПК II, 682). Зрідка бел входить до оказіональних словосполук, напр.: бела Вено, бела подунавке, / нарече се на Дунав на вода [приклад народноетимологічного «пояснення» причин появи означення] (ЉНП, 203).

Високої експресивності пісні нерідко досягнуто повторами усталених формул, насиченням тексту синонімічними щодо когнітивного спрямування зворотами, напр.: у тексті пісні з 14 тактових сегментів 11 безпосередньо чи через порівняння підпорядковані образному характеризуванню коханої: Заљубил Стојан Лилјана, / девојка лична убава, / заљубил Стојан Лилјана, / Лилјана бела, ирвена, / Лилјана m'нка висока, / Лилјана алоф трендафил, / Лилјана турски карамфил! / Што вели Стојан на мајка: / - Учи ме, мајко, карај ме, / како да земам Лилјана, / Лилјана бела, ирвена, / Лилјана m’нка висока, / Лилјана алоф трендафил, / Лилјана турски карамфил! (ЉНП, 73) ${ }^{19}$. Інший прийом, що відомий у різних фольклорних традиціях, - це повторення цілого такту з додатковим повторенням його частини в суміжному такті: оти е у́бава, бе́ла ем црве́на (повторено двічі) / бе́ла ем ирве́на, те́нка ем висо́ка (двічі) / те́нка ем висо́ка, цр́на, црноо́ка (двічі) (ММФ, 296); як наслідок - відчутно зростає оприявнення в тексті означення бел як маркера позитивної оцінки.

Хоча в макед. піснях означення бел не домінує серед засобів називання дівчини як об’єкта кохання чи замилування, усе ж цей питомий мовний знак не розчинився серед інших вербальних засобів, а у вторинній аксіальній функції зберіг тісне пов'язання з білим простором, залишився важливою структуротвірною рисою македонських пісень про кохання. Коло згадуваних у піснях реалій, вербалізованих з означенням бел-, доволі широке; окремі з них належать до високочастотних, що додає ваги таким елементам у творенні відповідної конотації. Білий простір макед. пісень об'єднує словосполуки на позначення реалій як ексклюзивних на тлі розглянутих укр. і болг. традицій, так і багатьох згадуваних у болг. і укр. піснях, що пов'язує між собою ці фольклорні традиції.

Призначення словосполук з бел- у текстах неоднакове: це або

а) елемент безпосереднього чи опосередкованого характеризування головної героїні пісні - дівчини, або

б) опис згадуваних у творі обставин, подій, реалій-атрибутів, часто пов'язаних із дівчиною як центральним об'єктом замилування, приязні.

\footnotetext{
19 Припускаємо, що саме такі орнаментовані багатьма стилістичними фігурами й символами тексти македонських народних пісень про кохання спонукали Д. Наневського до характеризування їх як «поетичної екібани, у якій немає жодної квітки без символізації чи прикраси без підтексту» (ЉHР, 6).
} 
Означення бел- у називанні дівчини чи іiі тіла (бе́ло ли́щуе, бели ращии 'б. руки’, бе́ла гу́ша 'б. шия', белото гр́ло, бели гр́ди) створює позитивну конотацію, яка в текстах до того ж часто посилена повторенням таких словосполук, а також згадуванням реалій, яким 3 природи притаманний білий колір (бело брашно, бе́ла ýpда 'сир', бели галабе (гулабе) 'голуби', бе́ла ко́јна і бе́ла а́та 'кінь', бело стадо (овець), бели варове 'вапно', бела книга 'папір') чи їх оприявнення як «білих» $\epsilon$ наслідком фольклорно-міфологічного осмислення дійсності. Що в доборі таких словосполук домінує не номінативна, а естетична засада народної словесності, виказує, по-перше, їх використання як усталеної структурної ознаки в піснях із різних регіонів Македонії; по-друге, промовистою є несумісність базового значення бел '[предмет] білого кольору' та онтологічних (природних) рис реалій, названих словосполуками з означенням бел (напр., у словосполуках-назвах бе́ла лоза / ло́зница 'виноградник', бел босиљок 'базилік', бело трнче 'терен' означення вказують не на білий колір реалій, а на їхню символьну / культурну значущість серед інших згадуваних об'єктів). Припускаємо, що й у контексті - Каља спие в градина, / под бел зелен трендафил [Дівчина Каля спить у садку під \{гарною\} трояндою] (ДМНП, 77) - складена номінація бел зелен так само відтворює не кольорову ознаку, а підкреслює загальну позитивну конотацію - піднесену тональність оповіді.

Відповідно до поетично-міфологічної моделі творення тексту пісень про кохання закономірним є використання означення бел в описах простору перебування дівчини, у називанні реалій, якими вона користується чи біля яких перебуває, хоча немає певності, що в таких випадках вказівка на білий колір реалій редукована сповна, пор.: бело одайче 'кімната (дівчини)', бело меко перниче 'м'яка подушка', бела постеља 'постіль', бели чадора 'намет', бела чешма 'криниця'). Означення бел часто оприявнене в назвах одягу дівчини (бело кръпче 'хустина, покривало на голову', бе́ли саи 'короткий верхній одяг' тощо), а нерідко - і поза контекстом опису дівчини, зокрема в тих випадках, коли реалія могла бути не білого кольору (бела риза, бе́лата цо́ка 'верхній одяг', бела промена 'одяг; гарний, святковий одяг', ‘білизна'); білий колір елементів одягу передбачуваний лише в окремих випадках, напр.: бела паче́ma 'в'язаний білий чоловічий головний убір'.

Зрозумілими і сприйнятними як засіб народнопоетичного словоладу є мікротексти з повторенням означення бел на зразок: бело и лице под бел трендайфил [iі біле обличчя під білою трояндою] (Пехчево - ММФ, 257). У макед. піснях дуже часто згадувані поняття хліба, інших хлібних виробів, які майже в усіх контекстах репрезентовані словосполуками з означенням бел-: бе́ло лепче, бела пога́ча, бел симит (бело симитче); так само майже послідовно трапляється синтагма бела пченица, а також зрідка, у зв’язку з останньою реалією, - і белија торби; назви грошей як поняття значиме (символ достатку, успіху) так само часто мають означення бел- (бели пари / бели грошове), зокрема і тоді, коли згадані карбовані iз золота монети (белото дубле 'турецька золота монета').

Важливою ознакою, спільною для укр., болг. і макед. пісень, є використання в тексті однієї пісні кількох словосполук із бел-, дериватів із цією основою, що посилювало конотацію білого як узагальненого поетичного образу, напр.: Сите 
моми тиквешанки / бело гројзи берат, / бело гројзи берат, мамо бре, / бели пари земат [ці дівчата-тіквешанки (Тіквеш - назва місцевості) збирають виноград і отримують хороші гроші] (Скопје - ММФ, 462); див. також: Дона бели, леле, бело платно, / Доне, белой моме, / на реката, леле, под върбата (ПК II, 231); Рамната става, белото лице, / Белото лице, белото грло, / Од јанаците - белите гради! (ЉНП, 101).

Посилення білого простору нерідко досягається через зіставлення 3 реаліями білого кольору, напр.: Какво́ е бе́ло гру́тка си́рење (“сир’), / такво́ е бе́ло мое́то ли́це (Делчево - ММФ, 331); ли́це и́ е бе́ло - тиквешка пуга́ча [обличчя ії таке біле, як хліб із пшениці з Тіквеша] (Гевгелиско - ММФ, 292); ли́це и е бело, ка́ко бе́ла кни́га (там само - ММФ, 293), белолика като бела книга (ЉНП, 128). Зауважимо, що вираз бела книга ('лист', 'папір') часто є елементом антитези бела книга - ирно писмо, яка оприявнена в багатьох макед. піснях (ЉНП, 227; ММФ, 190, 194, 199; ДМНП, 23, 70 та ін.); підкреслене протиставлення 'білий' ↔ 'чорний' у піснях реалізоване в протиставлюваних назвах різних реалій, що увиразнює символічне значення кольороназв.

У піснях із різних регіонів Македонії повторюється контекст зі згадкою сакральних об'єктів манастир, ирква, що в картині світу традиційно корелюють зі сферами чистого, урочисто-високого, а в поєднанні з елементами білого простору такий мікротекст зазнає відчутного употужнення, пор.: Што се белеје доле ју поле, / да н’ ми е магла, да н’ бела зора. / Нит бела магла, нит бела зора / туку ми била црква градена, / црква градена недоградена (ДМНП, 29).

У використанні словосполук із бел у макед. фольклорі спостережено таку саму багатоплановість, що і в укр. та болг. традиціях: на тлі синтагм на позначення реалій, віднесення яких до білого кольору закономірне й не викликає сумнівів, репрезентовано чимало реалій, які з природи можуть бути різного кольору, не лише білими, світлими (бело гројзе / грозде 'виноградні грона', бе́ла ракија 'горілка', бел камен 'камінь' тощо), або зовсім не корелюють з ознакою «білий» / «світлий, осяйний» (бела чешма 'криниця'). Природні іманентні ознаки реалій, названих такими словосполуками, у піснях зазнають деактуалізації; натомість посилюється поетико-міфологічний потенціал їхнього семантико-асоціативного поля, особливо за умови поєднання в тексті кількох синтагм з означенням бел-; індукцію білого простору внаслідок творення ампліфікаційних рядів з компонентом бел- демонструє багато макед. пісень різних локальних традицій.

Водночас у піснях історичних, побутових, яким притаманні інші змістові, аксіальні домінанти, так само трапляються словосполуки з означенням бел-, що переважно відтворюють білий / світлий колір позначуваних предметів і не входять до кола засобів передачі оцінності.

Ототожнення чи тісний зв'язок семантичних комплексів 'білий колір' і ‘позитивна оцінка' притаманні здебільшого пісням про кохання, приязнь: ці фольклорні тексти залишають стійке враження, що все оцінюване як гарне, позитивне, що є об'єктом схвалення чи замилування, може бути репрезентоване словосполукою з означенням бел-. У макед. традиції пряма номінація дівчини, молодої жінки (головного об'єкта пісень про кохання) - бела мома - трапляється значно рідше порівняно з укр. і болг. піснями відповідної тематики; водночас означення 
бел- і похідних від цієї основи широко представлені в називанні тих реалій і обставин, що безпосередньо чи опосередковано репрезентують дівчину / жінку.

Отже, наявний у македонському фольклорі білий простір виокремлюється як змістовий, естетичний і структурувальний складник, один із чинників формування й підтримування позитивної оцінки іменованих реалій та загальної конотації, створення окремої пізнаваної поетики пісенних текстів.

11.

Розглядаючи номінацію дівчини (насамперед у контексті *біла дівка) у сербському фольклорі, зазначимо, що означення бео в серб. мовному просторі репрезентоване широко, що засвідчують спеціальні студії (зокрема: Јанковић 2011) та тлумачні, етимологічний, діалектні словники. Багато елементів розгалуженого дериваційного і семантичного гнізда з основою бео належать до давніх, позначаючи реалії, поняття, зв'язок яких з гіпотетичним вихідним комплексом 'білий [за кольором]' є очевидним; водночас у багатьох назвах таке пов’язання реконструювати складно.

Вербалізація в серб. мовно-культурному просторі поняття «дівчина / молода жінка - об'єкт приязні, кохання» зосереджена насамперед у фольклорних текстах, де використано різні, неоднакові за частотою їх уживання, номінації. Зокрема, звертання бело девојће зафіксовано в поодиноких контекстах (ПЈС, 108, 135), як і синтагми бела + інша назва дівчини / молодої жінки - иура бела 'дівчина' (ПЛ, 152), бела була 'дружина мусульманина' (ПЛ, 76); проте часто засвідчено словосполуки бела + власне ім'я, напр.: бела Рада (БЛ, 22), бела Јана (ПЛ, 169, також: 43, 78, 154), бела Бојо, бело Ленще (ПЈС, 57, 64) тощо; у таких номінаціях, як і в болг., макед. традиціях, використано різноманітні антропоніми.

У серб. фольклорі бео оприявнено в різних контекстах: одні з них безпосередньо підпорядковані називанню дівчини, інші репрезентують елементи типового для народних пісень реалемного, ознакового й подієвого супроводу героїв відповідних текстів. Нерідко використано розгорнуті епітетні комплекси, до яких входить також означення бео; зокрема, це відомі й іншим південнослов'янським традиціям ряди означень, інколи розподілених між кількома синтагмами: Гајтан мома воду вади, / Над бунар се нагладује, / Да л’ је бела , је л' ирвена / Да л’ је танка, је л’ висока! (ПЛ, 56); Ој убава мала момо, ладо, ладо! / Изнакла ми конотацію / Доста m'нка и висока, / Доста бела и црвена (НПЛ, 46); Ајд слази, војно, од коња, / оће те наша девојка, / ти јој умно паметно, / ти си јој танко високо, / ти си јој бело румено (БЛ, 35 і 51, 53; див. також: ПЛ, 54, 125, 261, 262). Ампліфікуванням, до якого вдаються автори пісень, відчутно посилено оцінну коконотацію пісень, напр.: Ожени се сирома. / Узе мому од дома, / Танку, гиздаву, / Белу, румену / Црни ока, / Бела бока [...] Ал’ беседи гиздава, / Танка, бела, румена (СНП, 447-451). Використання поширених оцінних словосполук у поетичному називанні-характеризуванні дівчини зближує сербську фольклорну традицію з болгарською й македонською. 
У звертанні до дівчини та в називанні іï поза ситуацією звертання як означення до девојка, мома часто використано убава, лепа, млада, добра, драга, злата, напр.: Ој убава добра девојћо (БЛ, 17), лепа Мара за чудо убава (БЛ, 74), Ој убава, јубава девојћо, јубава добра девојћо́ (БЛ, 79). Нерідко у звертаннях до дівчини оприявнено назви квітів, дерев (рослинний код), що притаманне також укр., болг. і макед. фольклору; пор. у серб.: Ой дєвойко плава перунико 'синій ірис' (СП, 51), Станке, Јанке, ирвена јабуко (НПЛ, 103) тощо. Водночас сербські пісні вирізняє значно частіше порівняно з болг, макед. і укр. традиціями використання в звертаннях до дівчини лексеми душа (нерідко також - i дериватів від душу різноманітних поєднаннях з іншими вербальними засобами), чим досягалося увиразнення інтимізації висловлювання та загальна експресія тексту, пор.: душо; душо моя; душице моя; ой дєвойко душо; драга душо моя; ой дєвойко душиче тощо (СП, 47, 51, 71, 82, 85).

Репертуар понять білого простору серб. пісень має чимало елементів, спільних із болг. і макед. традиціями, що створює враження їх інтегральності. Проте назви тих самих реалій у континуумах різних мов і різних діалектів мають чимало відмінного. Спільним для зіставлюваних фольклорних традицій також $\epsilon$ насамперед поділ номінацій на два типи: які відтворюють ознаку реалії - білий / світлий колір, і які реалізують фольклорно-міфологічну модель номінації відповідних предметів, понять, хоча в текстах пісень така диференціація не завжди чітко виявлена, а обігрування внутрішньої форми означень, актуалізація вихідної семантики кольору в контекстах виразно метафоричних у серб. піснях належать до типових. Уявлення про наповнення й архітектоніку білого простору серб. фольклору дає наведений нижче тематичний реєстр:

назви людини - бела девојка, иура бела 'дівчина' (у весільній пісні), бел- + антропонім, бел белушка - звертання до немовляти (у колисковій пісні);

н. частин тіла людини (соматизми) - бијело лице (похідне - девојка белолика),

б. перси 'груди дівчини, хлопця', б. дојке 'груди дівчини, жінки', б. ноге, б. руке, б. грло, б. зуби, б. брада;

н. надприродних істот - б. вила;

н. полотна, сировини для виготовлення полотна, виробів з полотна, одягу та його деталей, взуття - по бијелу плату / платно 'полотно', б. сукна 'сукно', б. дари, б. сарука 'чалма, тюрбан', б. тулбен (тулбенче) 'тонке полотно (покривати голову)', б. (пребела) марама 'хустка, шаль', б. антарија 'жилет', б. свила (белом свилом шије) 'шовк', б. вустан (фустанче) 'спідниця', б. рукаве 'рукава в одязі', б. перје око калпака 'біла пір'їна - прикраса чоловічого головного убору', б. превез 'тонке покривало (на голову)', б. корпа 'шматок тканини', б. капа 'головний убір', б. кошуља, б. чарапе 'панчохи, шкарпетки', б. вуна 'вовна', б. вутарка 'сукня', б. тоска 'довга біла сорочка', б. дувака 'вельон нареченої', б. шала 'шаль', б. тулбен 'тонке полотно', б. премена 'одяг', б. брисаљка 'шматок тканини', б. торбе 'торба, мішок';

н. страв, борошна, хліба, виробів із тіста - б. млеко, брашно, б. љеб 'хліб' (нарани их љебом бијелием 'нагодуй ї [білим] хлібом'), б. колаче (умесим биеле колаче) 'білий хліб', пребеле симите 'куповані білі булочки', б. погач (У ратара црне руке, / А бєла погача) 'хліб; круглий прісний хліб', б. банища 'слоєний пиріг із сиром'; 
н. напоӥв - б. вино, б. пена (вина);

н. поселень, будівель, приміщень, елементів інтер'єру - б. град, назва міста + б. град (Од бијела града Варадина), б. стан 'табір, місце перебування', б. двор 'садиба; палац’, б. авлија 'дворище', б. кула 'башта', 'кам’яниця', б. крчма (пред бијелом крчмом) 'корчма', б. соба 'кімната', б. куће 'будинок, житло', б. ирква, б. манастир, б. чадор (бел чадор белеје) / б. шаторје 'намет', б. порти 'ворота', б. врата 'двері', б. душека 'подушка диванна';

н. тварин, птахів, комах та ӥхніх частин тіла - б. бељка 'куниця', б. јаре 'козеня', б. овц̧е і б. бейе (бецкк) 'вівця', б. ован 'баран', б. браве 'баран', б. јагањцуе 'ягнятко', б. стадо (овець), б. голуб (два бела голуба), б. голубица 'голубка', б. лабуд 'лебідь', б. гуска, б. врапче 'горобчик', б. перо 'пір'їна', б. пчеле 'бджоли'²;

н. рослин та ӥхніх частин - бијела, бјелица шеница (пченицуа) 'пшениця', б. гројзе 'виноград', б. лоза 'виноград', б. гижа 'виноградна лоза', б. босиљак 'васильки духмяні', б. цзвеће 'квітка', бел-црвен трендафил 'троянда; мальва', б. трюе 'терен', б. кроиња 'крони дерев', б. кор’јен (по б’јелу кор’јену) 'корінь', б. вишьа 'вишня', б. грах 'квасоля', б. пелин 'полин', б. ковиље 'ковила', б. травице;

н. об'єктів нежсивої природи, географічних об'єктів - б. снег 'сніг', б. зоре 'вранішня зоря' (поширений контекст: Зора зори, д’н се бели 'сходить зоря - розпочинає білий день' - ПЈС, 113, 149, 151), б. Дунав, б. пјена 'піна (у річці)', б. пепел;

н. обладунків воӥна, зброї, кінської збруї - б. латинка 'швидкострільна рушниця', пребели бедије 'підклад під сідло на коні переважно з білої тканини';

н. ужиткових предметів, подарунків - б. сребро 'срібло', б. пепел 'попіл', б. сапун 'мило', б. хартија 'лист, послання', б. книга 'книга; лист’, б. крошњь 'корзина (плетена з лози)', б. корпа 'корзина', б. дари і б. бошчалук 'подарунки учасникам весілля';

н. часових понять - б. дан 'день' (зора зори, дан се бели; бијел данак Ђурђев), б. подан 'полудень', б. зора (бела зора зазорила 'зійшла вранішня зоря');

н. грошових одиниць - б. пара (паре) 'гроші, монета', б. мещудије 'монети епохи Абдул-Меджида'.

Як і в інших розглянутих фольклорних традиціях, у серб. піснях у різних контекстах словосполуки 3 *bel- відтворюють притаманні реаліям ознаки за кольором, або дібрані за іншим принципом - позначають об'єкти задля створення фольклорно-міфологічного простору, досягнення бажаної оцінної конотації тексту безвідносно до природних характеристик об'єкта номінації. Висока фреквенція похідних від běl- у текстах та відчутне посилення оцінної конотації досягається завдяки використанню в тексті кількох бел-номінацій (Да си створим бели пепел, Да направим бели сапун, Да избелим бело лице [Напалимо \{потрібного зробимо \{хороше $\}$ мило і вибілимо \{гарне / біле $\}$ обличчя], Брза Лесковач НПЛ, 87), зверненню до тавтологічних синтагм (як-от: бели бело платно 'білить біле [= 'гарне'?] полотно', беле бели дворе 'прибирає [гарний?] двір'), а також повторенню тактів пісні з елементом бео (напр., у пісні із 30 рядків-тактів 10

${ }^{20}$ На тлі семантики беле пчеле ‘найдальші нащадки' (див. вище) у говірках також зафіксовано цілеспрямоване підкреслення зв’язку зі значенням 'білий колір': Што се онде лелејеше, лелејеше, белејеше? Да л’ је платно, е л’ је лабуд? Неје платно, неје лабуд, мори, тој су беле пчеле (ПЈС, 54). 
тактів є повтором фрази «Развијај, лице бело, развијај», а в іншій пісні з 10 рядків кожен другий $є$ епіфорою - «О лојзе, лојзе, сас бело гројзе!» - ПЛ, 284, 288; такі повтори $є$, ймовірно, одним із найпоширеніших прийомів формування фольклорного тексту, його важливою типологічною рисою). Běl-елементи (словосполуки із цим означенням, деривати, різноманітні фігури паралелізму з актуалізацією «білих» реалій) утворюють нелінійну надтекстову цілість, сітку структурних пов'язань, яка здатна індукувати оцінну конотацію, сприяти номінативній атракції - поширенню білого простору внаслідок використання означення бео в назвах інших реалій.

Крім бео, у сербських піснях задля позитивної аксіації названих реалій як постійні означення 3 вихідною семантикою чи вторинною семантикою кольору використано також злат і зелен, що впливає на наповнення, структуру білого простору, частотність оприявнення його елементів у текстах; значно рідше трапляються означення сив і црн.

Синонімізація означень (бео, злат і зелен), їх закріплення за об'єктами номінації не лише звужує простір використання бео як засобу досягнення позитивної оцінної конотації, а й трансформує сербський кольоровий код як елемент картини світу. У цьому переконує, зокрема, широке оприявнення злат і похідних у піснях, що втілюють концепт «світлий, осяйний». Словосполуками з означенням златнасамперед названо вироби із золота чи виготовлені з його використанням: злаћени прстени, злата бурма 'каблучка', златне брњице 'сережки', злат дьердан 'гердан', златне наруквице 'браслет', златна пуйа 'гудзик', златен венаи 'вінчальна корона, вінець', чаша позлаћена і златна купа 'чаша для вина', златни буздован 'булава', злаћене медаље 'медали' тощо. Водночас широким є сегмент золотого простору, який об’єднує реалії, які стосунку до золота як матеріалу не мають, а їхні назви є результатом метафоричної позитивної аксіації, усталеної фольклорної символізації відповідних предметів, понять, пор.: злато јабуко (у багатьох текстах), златна трава, златне гране 'гілка дерева', златна жица 'виноградна лоза', злат голуб (два златна голуба), злат соко 'сокіл', златна крила 'крила (соколиці)', утва златокрила 'качка', злате роге 'роги', грива (коня) позлаћена, златне чешли 'гребінець для волосся', злате вретено 'веретено (для прядіння)', злата преслица 'прядка', злата марама 'хустка', злата љула 'колиска', злата тепсија 'противень, жаровня', златни кове 'відра', злаћене столове 'золочені столи', златна струга 'місце доїння овець, струнга'; у юнацьких піснях означення злат- і (похідні) часто трапляються як засіб поетизації дійових осіб у назвах зброї, спорядження, одягу, інших атрибутів, що засвідчують, на думку авторів, звитягу воїнів: златни топи 'гармати' (Златни топи у град ударише СНП I, 89), пушке позлаћене 'пістолі', (скида) златна шестлопериа 'різновид зброї - пернач', златна тетива, злаћене ножеве 'ножі', узда позлаћена 'вуздечка коня'; пор. також: Предъ войскомъ е Божко Юговичу / На алату васъ у чистом злату, [...] / На баряку одъ злата ябука, / Из ябуке одъ злата крстови, / Одъ крстова златне ките висе [Перед військом [...] на коні весь у золоті [...] На прапорі при золотій кульбаці сідла; біля кульбаки золотий хрест, із хреста звисають золоті тороки-прикраси] (Сремски Карловиц - CП, 223; див. також: CHП IV, 59); інша сфера широкого використання означення злат - весільні пісні, пор. 
поширену в болг, макед. і серб. піснях формулу своєрідного заперечення-ствердження: Повила се златна жица из ведра неба [...] / То не била златна жица из ведра неба, / Већ то била лепа Ружа от добра рода [Повилася з ясного неба золота виноградна лоза... То не золота лоза із ясного неба, а то була Ружа - гарна дівчина доброго роду] (СНП I, 91); інший показовий приклад насичення пісні злат-: Фалилася Мара роду / Да ће сијат' златом гору, / Да ће нацат' златом дубље, / испод дубља златна трава, / Испод траве бистра вода (Бијела Црна Гора - ПЦГ, 135). Сформованість золотого простору з виразною позитивною оцінною конотацією уможливила використання словосполук мое злато у звертанні до коханої дівчини, златни куме (звертання у весільній пісні), златни златари 'майстри-золотарі', як і називання визнаної історичної особи через алюзію до злато (Цар Лазаре Србска круно златна! [Царю Лазаре, золота короно Сербіі] - СП, 222).

Зауважимо, що в болг. і макед. фольклорних традиціях так само часто використано означення злат, зокрема у вторинній метафоричній функції, насамперед як суперлятивна характеристика позначуваної реалії, напр. макед.: ја питале чија вера сака. / Јас си сакам нашта златна вера (Воденско - МПВ, 53); пор. також зразок насичення тексту згадками про злато в пісні з макед. Струмиці: момче, ќе ти купам до сто драма злато, / момче, да направеш един златен розбој; / момче, шо ќ' устане един златен пръстен (парубче, коли ти купиш сто драм [“стара одиниця ваги'] золота і зробиш \{з нього 3 золотий ткацький верстат, то отримаєш золотий перстень, ММФ, 359); інше заняття дівчини - прання одягу, полотна на березі річки та прядіння - так само супроводжено використанням означення злат: златна буалка 'праник (для вибивання білизни при пранні)' і златно вретено 'веретено' (Горночумајско - Стоилов 1990, 42). Проте в серб. традиції фреквенція злат як засобу позитивного оцінювання номінованих реалій значно вища. Важливою є синонімізація означень злат і зелен, що відтворено народними піснями, де функційно тотожними є злато јабуко і зелено јабуко з виразною позитивною аксіацією, пор.: Ко ђевојка зеленом јабуком; у звертанні - Брате Гојко! зелена јабуко (CHП IV, 191, 238); так само паритетними є зелен соко і од злата сокола (СНП IV, 416) ${ }^{21}$.

Інша примітна риса серб. пісень на тлі болг. і макед. - це наявність виразних тенденцій використання означення běl- та означень-еквівалентів у назвах річок

\footnotetext{
21 Дослідження семантики означення зелен у серб. мовно-культурному просторі (зі спеціальною увагою до фольклору) уможливило обгрунтування кількох ліній ії розвитку, зокрема розгортання завдяки дериватам і словосполукам номінативного поля *zelen зі збереженням зв'язку: а) зі значенням 'зелений колір', б) з комплексом значень 'світлий', 'осяйний' і в) із загальною позитивною оцінкою іменованих реалій унаслідок їх поетико-міфологічного характеризування за канонами творення фольклорних текстів; звідси - закономірна поява в серб. піснях словосполуки зелен соко 'сокіл' на тлі усталеної сив соко, а також випадки розширення структури цієї синтагми додаванням другого означення сив-зелен сокол (СП, 79); на широку реалізацію метафоричної позитивної аксіації вказує багато назв зброї - zelen тас̌ ('меч'), zelena sablja ('шабля'), zelena puška ('стрілецька зброя'), zelen top ('гармата’), а також zelena ruka - символ звитяги юнака-воїна (Ivić 1995, 98-99). М. Івіч підкреслює, що поява в цих словосполуках-назвах епітета zelen зумовлена не зеленим кольором реалій, а оцінно-прагматичною настановою: «zato da bi se tim epitetom naglasila njihova podobnost za efikasno delovanje radi savlađivanja protivnika» (Ivić 1995, 100).
} 
і міст. Якщо в болг., мак. піснях як означення до Дунав відчутно переважає бел (бял) над тих, що трапляється лише спорадично, то в серб. піснях зафіксовано ситуацію протилежну: значне поширення означення тих (варіанти тиха, тиа, тија) Дунава на тлі окремих випадків з бел-, пор. у серб. піснях: Тамо доле крај тија Дунава (СНП I, 296); пак он плива по тијо Дунаво (СНП I, 510); Ој Дунаве, mија водо! (CHП I, 431)22; назви інших річок супроводжують означення тих (отиде низ тиу Мораву - СП, 112) чи ладна (< хладна), валовита 'бурхлива': Украй Саве воде ладне (СНП I, 196, 257); нерідко кілька означень творять ампліфікаційний ряд: Саво водо валовита ладна (СП, 318).

Іншу тенденцію функціонування означень засвідчують контексти з назвами міст. Зокрема, у болг. піснях типовою $є$ поширена словосполука ойконім + града голема (Във Преслав града голяма - СИБ, 607; нах Солун града голеิма - СрРП, 361; див також: 192, 296, 410, 425, 485; в окремих випадках голем- стосується села: село големмо (СрРП, 106); лише в поодиноких випадках зафіксовано словосполуку бели град (Илей Йоване / бели гражданино, / оберни се, / бели град изгоре - ПК I, 398; варіант пісні в: РП, 393). Зауважимо, що традиційна для болг. пісень сполука голяма града не зумовлює перенесення означення голем- у семантично ідентичну словосполуку, якщо питома лексема град субституйована запозиченою лексемою касаба 'місто'. У серб. піснях у цій ситуації використано означення бео, причому такі словосполуки частовживані, кількісно переважають над контекстами використання ойконімів без означення, що дає підстави припускати клішованість структури ойконім + бео град; напр., у зібранні В. Караджича

${ }^{22}$ На тенденцію закріплення в болг. фольклорній традиції за гідронімом Дунав означення бел (бял), а в серб. - тих звернув увагу В. Ягич, водночас зауваживши, що в болг. піснях зрідка також трапляються словосполуки тиха Дунава, тихи Дунав (Jagić 1876, 301); останнє підтверджує використання контамінованих означень, напр.: през тиха бели Дунаве; през тихиян, тихьян бели Дунав у Родопах (РП, 99, 115; див. також: СрРП, 334, 436); так само - у піснях із регіонів Преславско, Шуменско, Новопазарско, Торговищко (СИБ, 146, 180, 289, 308, 361, 454, 661). М. Івіч прокоментувала контексти використання в серб. фольклорних і художніх текстах словосполуки бел Дунай (Ивић 2001, 16), підтвердивши давніші спостереження В. Ягича про нестроге закріплення типів означень у синтагмах бел (бял) Дунав і тих Дунай відповідно за болг. і серб. мовно-культурними континуумами, можливість їх поширення за межами основного ареалу - у латеральних зонах суміжного континууму. Цінним є спостереження В. Ягича про зміну в південнослов'янському мовно-культурному просторі змісту назви Дунав / Дунай, зневиразнення зв'язку назви Дунай із відповідним реальним гідрооб'єктом. Було зауважено, що із віддаленням від річки Дунай увиразнюється вторинний народноміфологічний складник в осмисленні гідроніма Дунай аж до повного затирання відношення до реального водного об’єкта, перетворення власної назви у назву загальну, у фольклорний образ, співвідносний із загальним поняттям річка (будь-яка); водна перепона чи будь-яка інша перепона, яку необхідно подолати; щось великого розміру; щось позитивно оцінюване (Jagić 1876). Спостереження В. Ягича про зміну функцій гідроніма Дунай у парадигмі народної культури релевантні для розуміння процесів i в укр. фольклорі, де Дунай як народнопоетичний образ, по-перше, кількісно відчутно переважає згадування широковідомої центральної ріки України Дніпра (Аркушин 1981, 69), а по-друге, у багатьох випадках виявлено виразну редукцію зв'язку з річкою Дунай як відповідним гідрооб'єктом; останне типологічно однакове із ситуацією, засвідченою в південнослов'янському континуумі. Ізоглоса тихий Дунай об'єднує серб., болг. і укр. фольклорні традиції; формування ізоглоси відбулося, імовірно, шляхом поширення вже усталеної народнопісенної словосполуки із серб.-болг. ареалу в регіон Карпат із подальшим ї̈ закріпленням у фольклорі всього укр. континууму, а згодом - i широким входженням у художню літературу (рух цієї мовної риси від укр. народних пісень до художніх текстів відтворено в: Єрмоленко 1987, 187-188; Дядищева-Росовецька 2001, 109-114; Мовчанюк 2004). 
Песме јуначке новијих времена засвідчено: до бијела града Дубровника; у Клобуку граду бијелому; више Спужа града бијелога; од бијела града Варадина; отиде Нишу бијеломе; од Лознице од бијела града; од Стамбола б’јела; у Зети три бијела града (CHП IV, 38, 71, 74, 111, 164, 171, 260); лише в цьому джерелі на позначення міст зафіксовано понад 40 словосполук такої структури (частина 3 них неодноразово повторюється в різних піснях), а синтагми з означенням велик - факти одиничні, напр.: опреми је великом Видину (CHП IV, 162).

Отже, наявні виразні ареальні протиставлення, що сигналізують про існування і збереження в пісенному просторі важливих маркерів віддавна сформованих етнічних картин світу. У кожній локальній фольклорній традиції для досягнення бажаного емоційного ефекту, посилення оцінної конотації існував широкий відносно сталий набір вербальних засобів (мовних елементів, їх синтактики, моделей наповнення слів і словосполук метафоричним і міфологічним змістом), що були відомі авторам і виконавцям народних пісень, які усвідомлювали й широко використовували естетичний потенціал таких структурних одиниць. Коло таких засобів (насамперед закріплення означень як сталих у вживанні; наявність неузуальних означень-метафор, притаманних лише фольклору; наявність надлишковості, дублювання означень у синтагмах), широке використання таких словосполук у різних піснях віддалених між собою теренів указують на їх архаїчність, формування у віддаленому минулому. Інтегральними для сербської, болгарської й македонської фольклорних традицій виявилися не тільки ізоглоси - словосполуки з означення *bel як мовні знаки, та ряди однакових реалій, вербалізованих варіативно, залежно від лексичної диференціації діалектного простору, джерел та інтенсивності іншомовних впливів на діалекти, відповідно - i тексти пісень, а й спільна модель зв’язку концептів «білий / світлий / осяйний» і «гарний / позитивний» - ізопрагма, що породжує, підтримує ізоглоси, у яких вона реалізована.

Неповторність кожної національної фольклорної традиції оприявнена, зокрема, наборами ексклюзивних синтагм (також і з означенням *běl-), структурами номінативних, дериваційних полів назв кольорів, виразними тенденціями частотності використання кольоративів як постійних епітетів, особливостями синонімії. Спостережено, що архітектоніка тексту, прийоми його творення та підпорядкування визначальним для пісні концептам та міфологічному змісту образів мають неповторні риси в зіставлюваних фольклорних традиціях, хоча їх об'єднують інтегральні вербальні, образні елементи, зокрема *біла дівка та багато компонентів білого простору.

\section{Деякі узагальнення}

1. Спостереження над українськокарпатськими, болгарськими, македонськими й сербськими народними піснями засвідчили наявність спільних / близьких формальних і змістових елементів кольорових кодів у цих культурних традиціях. Серед інтегральних ознак виявлено: 
а) поширення в піснях назв дівчат, молодих жінок, хлопців словосполуками 3 означенням běl- (умовно - *біла дівка), численні контексти яких засвідчують актуалізацію оцінних конотацій, що нерідко є невід'ємним супроводом їх використання в піснях;

б) феномен *біла дівка функціонує на тлі білого простору - багатокомпонентного номінативного поля, що об'єднує пов'язані між собою різноманітні за семантикою синтагми з означенням běl- та деривати від цієї основи; білий простір як одна 3 домінант (в окремих культурних ареалах - визначальний складник) кольорового коду народних пісень виявився важливим елементом народнопісенної поетики розгляданих фольклорних традицій;

в) білий простір об’єднує як назви реалій за ознакою білого, світлого кольору, так і численні метафоричні назви, якими вербалізовано образи, моделі аксіації, що притаманні міфологічному фольклорному дискурсу;

г) важлива інтегрувальна риса поетики фольклорних текстів, що репрезентують різні культури, - це цілеспрямоване посилення оцінних конотацій běl-, зокрема через насичення текстів пісень синтагмами з цим елементом та дериватами, що зумовлює номінативну індукцію - використання означення běl- у називанні нових об'єктів;

г) семантичні, асоціативні комплекси 'колір' і ‘оцінка' словосполук-номінацій 3 означенням běl- у багатьох пісенних контекстах співіснують як неподільна єдність; їх цілеспрямоване протиставлення нерідко $є$ основою тропів, словесною грою.

2. Спільні номінативні, семантичні й аксіальні ознаки зіставлюваних мовно-культурних континуумів грунтуються на близькості, тотожності фрагментів фольклорно-міфологічних картин світу цих слов'янських народів, хоча кожній із традицій притаманний високий ступінь неповторності, ексклюзивності.

Лексична спільність (ізоглоси), близькість / тотожність окремих елементів та архітектоніки сегментів картин світу (ізопрагми) надійно підтверджені високою фреквенцією (повторюваністю) аналізованих словосполук 3 компонентом *bělу піснях із різних теренів розгляданих континуумів, наявністю різноманітних усталених (клішованих) формул у численних текстах, що унеможливлює пояснення виявлених у зіставлюваних фольклорних традиціях однакових структурних елементів, моделей семантичного розвитку як випадкових збігів. Останнє спонукає до пошуку інших причин і шляхів їх постання; серед можливих типових версій - це

а) продовження в аналізованих оприявненнях словесної культури архаїчного спільного прастану чи

б) формування внаслідок тривалих у часі тісних міжетнічних / міжкультурних контактів багатьох спільних елементів. Імовірність взаємодії чинників $a$ і $\sigma \epsilon$ високою, до чого можуть долучатися окремі (випадкові) збіги; допустимість різних передумов формування ізоглос, ізопрагм актуалізує їх верифікацію.

3. Закономірний характер ізоглосних пов'язань фольклору зіставлюваних слов'янських континуумів підтверджують численні спільні елементи білого проcтору (зокрема серед назв людини, реалій тілесного, рослинного, тваринного, предметного, гастрономічного кодів), ізоструктури - типи усталених зв'язків між 
елементами (як відношення синонімії «білий» - «золотий» - «світлий» / «осяйний», антонімії «білий» $\leftrightarrow$ «чорний» 23$)$, однакові стійкі конотації для номінацій з означенням *běl-.

4. Об'єднуючи однакові чи близькі мовні елементи, явища в різних слов'янських континуумах, ізоглоси нерідко співвіднесені з неоднаковими топосними ситуаціями: спільний для кількох континуумів лінгвальний знак у просторі однієї мови може належати до високочастотних одиниць, в іншій - до спорадично оприявнених, засвідчених поодинокими контекстами; у континуумі однієї мови ізоглосна лінгвальна одиниця може входити до дериваційного (формального, семантичного) гнізда на противагу iii ізольованому становищу в континуумах інших мов; неоднаковими в різних мовах / культурах можуть бути й конотації спільних елементів. Тому виявлення ізоглоси, що засвідчує міжконтинуумну структурну ідентичність / близькість, передбачає іiі змістову, функційну параметризацію за різними ознаками.

5. Значну цінність зберігають неізоглосні структурні елементи, виявлені в просторі однієї мови й не зафіксовані в інших мовах; репертуар таких одиниць доволі широкий, що підтверджує неповторну історію формування й розвитку кожного зі слов'янських мовно-культурних ідіомів. Віднесення номінативних засобів, їх семантики до кола ексклюзивних передбачає попередню перевірку їх неізоглосності, унікальності через цілеспрямоване обстеження інших континуумів, що $\epsilon$ важливим інструментом поглибленого виявлення й аналізу міжмовної / міжкультурної взаємодії.

6. Виокремлення в *běl- семантичного комплексу 'гарний, красивий', його поширення в досліджуваному сегменті карпато-балканського макроареалу актуалізує необхідність з'ясування генези цього семантичного феномену в кожній із аналізованих мов; адже розв'язання давно сформульованої історико-семасіологічної альтернативи - чи:

а) оцінний (аксіальний) складник семантики *běl- 'гарний, красивий / позитивний' $є$ вторинним стосовно позначення кольору, який постав унаслідок семантичної деривації за моделлю «колір (білий)» $\rightarrow$ «(позитивна) оцінка», чи

б) «(позитивна) оцінка» $\epsilon$ результатом розвитку давнішого синкретичного комплексу «сяючий / світлий / з блиском», із якого могли постати окремі значення 3 кола позитивної оцінки - не зовсім очевидна. Тому М. Івіч, проаналізувавши неоднакові передумови закріплення означення бео в назвах реалій різних класів, висловила припущення про можливість ““уведення в гру” [...] збереженого в народній пам’яті прастарого значення (білий = 'світлий’)» (Ивић 1999, 16).

7. У студії (в опорі на фольклорні тексти) увагу зосереджено на явищах мови i культури передусім через призму їхнього просторового буття, оприявнення. Просторова домінанта пізнання, осмислення елементів і явищ у контексті просторових змін, варіювання закономірно актуалізує проблему надійності фольклорного, зокрема пісенного, матеріалу як джерела зіставних i, особливо, ареалогічних

\footnotetext{
23 Про окремі ізоструктури та їх вербалізацію з використанням усталеного протиставлення 'білий' $\leftrightarrow$ 'чорний' у карпато-балканському гетерогенному макроконтинуумі див.: Siatkowski 2001; Гриценко 2008 .
} 
досліджень - лінгвістичних й етнолінгвістичних, культурологічних. До питань картографічної презентації й просторової верифікації свідчень фольклору дослідники поверталися неодноразово в теоретичних студіях (Плотникова 2013, 123-142), спираючись також на досвід картографування за фольклорними текстами та досвід створення карт за даними народної словесності та діалектного мовлення в їх зіставленні (напр.: Bartmiński 1973; Sierociuk 1990); така практика виявилася цінною для з'ясування стану збереження / змінності структурних елементів фольклору, їх зв'язку з діалектним довкіллям.

Наведеними спільними карпато-південнослов'янськими мовними рисами, пов'язаними з концептуальним ототожненням «білий»= «гарний»у ф фольклорному дискурсі, окреслено контури кола ширшої проблеми: межі й доцільність залучення народної словесності до виявлення й аналізу зв'язків, напрямків взаємовпливів мов / культур, зокрема і в цьому етнічно строкатому й історично складному сегменті європейського простору.

Припускаємо, що аналіз інформації з інших мов південнослов'янського / балканського і карпатського континуумів, а також розширення бази даних (насамперед фольклорних і діалектних текстів), частково репрезентованих у цій студії слов'янських мовно-культурних традицій, уможливить уточнення топосу ізоглоси *біла дівка, сприятиме з'ясуванню просторового варіювання білого простору та окресленню його лінгвістичного змісту, а також оприявнить нові ізоглоси, ізопрагми з притаманною їм топографією та неповторною історією.

Важливо, що фольклорні тексти переконливо засвідчили наявність широкого кола ізоглосних пов'язань елементів, які належать до засобів фольклорної поетики, маркерів відповідних національних культур, а не до загальномовних узуальних одиниць.

Тому в пізнанні сутності карпато-балканської спільності / близькості різноманітним свідченням фольклору належить така сама роль, як і вивченню власне мовних рис - фонетичних, лексичних, граматичних.

\section{Джерела}

БЕР, Български етимологичен речник [Balgarski etimologichen rechnik], т. 1-. София, 1971-.

БЛ, Бела лоза. Свадбене песме Сврљишког краја [Bela loza. Svadbene pesme Svrljiškog kraja], прир. Н. Бодановић [N. Bodanović], Ниш, 2000.

БНТ, Българско народно творчество: в $12 \mathrm{~m}$. [Balgarsko narodno tvorchestvo: $v 12$ t.], т. VI: Любовни песни, отбр. и редакт. Д. Осинин, И. Бурин [D. Osinin, I. Burin], София, 1962.

Воллан, Угро-русскія народныл пғсни [Ugro-russkiya narodnyya pesni], собр. Г.А. Де-Воллан [G.A. De-Vollan], С.-Петербургъ, 1885.

Гнатюк В. [Hnatiuk V.] (1905-1907), Коломийки [Kolomyiky], зібрав В. Гнатюк, т. I-III, Львів.

Грицак М.A. [Hrytsak M.A.] (2017), Матеріали до Словника українських говірок Закарпатської області [Materialy do Slovnyka ukrainskykh hovirok Zakarpatskoi oblasti], вип. 1: $A-Б$, Київ. 
Грицак М.A. [Hrytsak M.A.], Картотека Словника українських говірок Закарпатської області [Kartoteka Slovnyka ukrainskykh hovirok Zakarpatskoi oblasti], зберігається в Інституті української мови НАН України (м. Київ).

ДМНП, Двогласни македонски народни песни [Dvoglasni makedonski narodni pesni], изб. и ред. Т. Бицевски [T. Bicevski], Скопје, 1988.

ЕРСЈ, Етимолошки речник српског језика [Etimološki rečnik srpskog jezika], т. I-, Београд, 2003-.

Златковић Д. [Zlatkoviћ D.] (2014), Речник пиротског говора [Rečnik pirotskog govora], т. I-II, Београд.

ЗП, Народни песни от Западните Покрайнини [Narodni pesni ot Zapadnite Pokraynini], нотирал и записал В. Стоин [V. Stoin], София, 1959.

Илчев C. [Ilchev S.] (1969), Речник на личните и фамилни имена у българите [Rechnik na lichnite i familni imena u balgarite], София.

К, Коломийки [Kolomyiky], упорядн. Н.С. Шумада [N.S. Shumada], Київ, 1969.

Кауфман Н. [Kaufman N.] (1982), Народни песни на българите от Украинска и Молдавска CCP [Narodni pesni na balgarite ot Ukrainska i Moldavska SSR], т. I-II, София.

Куняк, Коломийки Прикарпаття [Kolomyiky Prykarpattia], упорядн. Я. Куняк [Ya. Kuniak], Івано-Франківськ, 2006.

Лінтур, Народні балади Закарпаття [Narodni balady Zakarpattia], упорядник П.В. Лінтур [P.V. Lintur], Ужгород, 1959.

ЉНР, Љубовни народни песни [Ljubovni narodni pesni], изб. и ред. Д. Наневски [D. Nanevski], Скопје, 1971.

ММФ, Македонски музички фолклор. Песни [Makedonski muzički folklor. Pesni], т. II. Скопје, 1959.

МПВ, Македонски народни песни од Воденско [Makedonski narodni pesni od Vodensko], изб. и ред. Т. Бицевски [T. Bicevski], Скопје, 1989.

МПК, Македонски народни песни од Кукушко [Makedonski narodni pesni od Kukuško], изб. и ред. Т. Бицевски [Т. Bicevski], Скопје, 1989.

Негрич М. [Nehrych M.] (2008), Скарби гуиульського говору: Березови́ [Skarby hutsulskoho hovoru: Berezovy], Львів.

НПК, Народни песни от Карнобатския край [Narodni pesni ot Karnobatskiya kray], зап. и съст. Д. Тодоров [D. Todorov], София, 1994.

НПЛ, Народне песме из Лесковачке области [Narodne pesme iz Leskovačke oblasti], сукуп. Д.М. Ђорђевић [D.M. Đorđević], прир. М. Златановић [M. Zlatanović], Београд, 1990.

Онишкевич М.Й. [Onyshkevych M.Y.] (1984), Словник бойківських говірок [Slovnyk boikivskykh hovirok], ч. I-II, Київ.

ПЈС, Народне песме и басме Јужне Србије [Narodne pesme i basme Južne Srbije], сукуп. и прир. М. Златановић [M. Zlatanović], Београд, 1994.

ПК І, Народни песни от Югозападна България. Пиринский край [Narodni pesni ot Yugozapadna Balgariya. Pirinskiy kray], т. I, съст. Н. Кауфман, Т. Тодоров [N. Kaufman, т. Todorov], София, 1967.

ПК ІІ, Народни песни от Югозападна България. Пиринский край [Narodni pesni ot Yugozapadna Balgariya. Pirinskiy kray], т. II, съст. Н. Кауфман, И. Манолоов [N. Kaufman, I. Manoloov], София, 1994. 
ПЛ, Васиљевић М.A. [Vasiljević М.А.] (1960), Народне мелодије Лесковачког края [Narodne melodije Leskovačkog kraya], Београд, 1960.

Пујић C. [Pujić S.] (2013), Хериеговачка пчеларска лексика (на општесловенској основи) [Hercegovačka pčelarska leksika (na opšteslovenskoj osnovi)], «Српски дијалектолошки зборник», LX, c. 463-804.

ПЦГ, Васиљевић М.А. [Vasiljević М.А.] (1965), Народне мелодије Црне Горе [Narodne melodije Crne Gore. Београд, 1965.

РБЕ, Речник на българския език [Rechnik na balgarskiya ezik], т. I-. София, 1977-.

Ребошапка - Відгомін віків. Збірка народних балад, історичних пісень та пісень-хронік [Vidhomin vikiv. Zbirka narodnykh balad, istorychnykh pisen' ta pisen-khronik], зібр. і упоряд. I. Ребошапка [I. Reboshapka], Бухарест, 1974.

РП, Народни песни от Родопския край [Narodni pesni ot Rodopskiya kray], сост. Н. Кауфман, Т. Тодоров [N. Kaufman, T. Todorov], София, 1970.

РСКНЈ, Речник српскохрватског књижевног и народног језика [Rečnik srpskohrvatskog književnog i narodnog jezika], т. 1-, Београд, 1959-.

Сабадош I.B. [Sabadosh I.V.] (2008), Словник закарпатської говірки села Сокирниия Хустського району [Slovnyk zakarpatskoi hovirky sela Sokyrnytsia Khustskoho rajonu], Ужгород.

Савчук - Шідарідайдана: Коротенькі співаночки або коломийки, які записав упродовж 1975 - 1989 років Микола Савчук у селі Великий Ключів Коломийського району Івано-Франківської області [Shidaridaidana: Korotenki spivanochky abo kolomyiky, yaki zapysav uprodovzh 1975 - 1989 rokiv Mykola Savchuk u seli Velykyi Kliuchiv Kolomyiskoho rajonu Ivano-Frankivskoi oblasti], Івано-Франківськ, 1999.

Сбук, Словник буковинських говірок [Slovnyk bukovynskykh hovirok], ред. Н.В. Гуйванюк, К.М. Лук'янюк [N.V. Huivaniuk, K.M. Lukianiuk], Чернівці, 2005.

СЗПГ, Аркушин Г. [Arkushyn Н.] (2016), Словник західнополіських говірок [Slovnyk zakhidnopoliskykh hovirok], Луцьк.

СИБ, Народни песни от Североизточна България [Narodni pesni ot Severoiztochna Balgari$y a$ ], т. II, сост. И. Качулев [I. Kachulev], София, 1973.

CHП I, Караџић В. [Karadžić V.] (1975), Спрске народне пјесме [Sprske narodne pjesme], т. I, Београд.

CHП IV, Караџић В. [Karadžić V.] (1986), Спрске народне пјесме [Sprske narodne pjesme], т. IV, Београд.

Сокіл ${ }^{\mathrm{a}}$ Волосянка у фольклорі та говіриі [Volosianka u folklori ta hovirtsi], зібрав та впорядкував В. Сокіл [V. Sokil], Львів, 2016.

Сокіл ${ }^{6}$, Народні пісні з голосу Параски Павлюк [Narodni pisni z holosu Parasky Pavliuk], зібрав та упорядкував В. Сокіл [V. Sokil], Львів, 2009.

Сокіл ${ }^{\mathrm{B}}$, Фольклорні матеріали з отчого краю [Folklorni materialy z otchoho krayu], зібрали В. Сокіл, Г. Сокіл [V. Sokil, H. Sokil], Львів, 1998.

CП, Караџић В. [Karadžić V.] (1965), Пјеснариияa 1814-1815 [Pjesnarica 1814-1815], Београд.

СрРП, Народни песни от Средните Родопи [Narodni pesni ot Srednite Rodopi], записал А. Райчев [A. Raychev], София, 1973.

Стоилов А.П. [Stoilov А.P.] (1990), Македонски народни песни [Makedonski narodni pesni], ред. М. Китевски [M. Kitevski], Скопје. 
УФЕ, Украӥнська фольклористична енциклопедія [Ukrainska folklorystychna entsyklopediia], ред. В. Сокіл [V. Sokil], Львів, 2018.

Шило Г.Ф. [Shylo H.F.] (2008), Наддністрянський ретіональний словник [Naddnistrianskyi regionalnyi slovnyk], відп. ред. Л. Полюга, Н. Хобзей [L. Poliuha, N. Khobzej], Львів Нью-Йорк.

Janów J. (2001), Stownik huculski, oprac. i przygot. do druku J. Rieger, Kraków.

Rieger J. (1996), A Lexical Atlas of the Hutsul Dialects of the Ukrainian Language, Warsaw.

Rieger J. (2017), Atlas ukrainskich gwar nadsańskich, t. I-II, Warszawa.

\section{Література}

Алмалех М. [Almaleh M.] (1997), Цветовете в балканския фолклор. Езикът на иветовете [Tsvetovete v balkanskiya folklor. Ezikat na tsvetovete], София.

Аркушин Г.Л. [Arkushyn H.L.] (1981), Улюблена народна ріка [Uliublena narodna rika], «Культура слова», 21, Київ, с. 68-72.

Белова O.В. [Belova O.V.] (1999), Красный ичвет [Krasnyj cvet], [в:] Славянские древности. Этнолингвистический словарь в $5 \mathrm{~m}$. [Slavyanskie drevnosti. Etnolingvisticheskij slovar $v 5$ t.], т. 2, Москва, с. 747-751.

Белова О.В. [Belova O.V.] (2012), Цвет [Cvet], [в:] Славянские древности. Этнолингвистический словарь [Slavyanskie drevnosti. Etnolingvisticheskij slovar в 5 m.], т. 5, Москва, c. $474-476$.

Бернштейн С.Б. [Bernshtejn S.B.] (1948), Разыскания в области болгарской исторической диалектологии [Razyskaniya v oblasti bolgarskoj istoricheskoj dialektologii], т. 1: Язык валашских грамот XIV-XV веков [Yazyk valashskih gramot XIV-XV vekov], Москва - Ленинград.

Бјелетић М. [Bjeletić М.] (2001), Беле пчеле [Bele pchele], «Кодови словенских култура», бр. 6: Боје, Београд, с. 106-118.

Богатырев П.Г. [Bogatyrev P.G.] (1958), Некоторые задачи сравнительного изучения эпоса славянских народов [Nekotorye zadachi sravnitelnogo izucheniya eposa slavyanskih narodov], Москва.

Вендина Т.И. [Vendina T.I.] (2000), Семантико-символическая парадигма ивета в контексте словообразования [Semantiko-simvolicheskaya paradigma cveta v kontekste slovoobrazovaniya], «Etnolingwistyka. Problemy języka i kultury», 12, c. 189-203.

Гриценко П. [Hrytsenko P.] (2008), Carpato-balkanica в свете «Общекарпатского диалектологического атласа» [Carpato-balkanica v svete «Obshchekarpatskogo dialektologicheskogo atlasa»], [в:] Карпато-балканский диалектный ландшафт: Язык и культура. Памяти Галины Петровны Клепиковой, Москва, с. 26-57.

Гриценко П. [Hrytsenko P.] (2009), Carpato-balkanica. 2. Українсько-хорватські паралелі на картах Загальнослов'янського лінгвістичного атласу [Carpato-balkanica. 2. Ukrainskokhorvatski paraleli na kartakh Zahalnoslovianskoho linhvistychnoho atlasu], «Studia 
methodologica», вип. 27: Лемківський діалект у загальноукраӥнському контексті, c. $5-12$.

Дядищева-Росовецька Ю. [Diadyshcheva-Rosovetska Yu.] (2001), Фольклор і поетичне слово Tapaca Шевченка [Folklor i poetychne slovo Tarasa Shevchenka], Київ.

Евгеньева А.П. [Evgeneva А.Р.] (1963), Очерки по языку русской устной поэзии в записях XVII-XX в8. [Ocherki po yazyku russkoj ustnoj poezii v zapisyah XVII-XX vv.], Москва.

Ермоленко С.Я. [Yermolenko S.Yа.] (1987), Фольклор і літературна мова [Folklor i literaturna mova], Київ.

Иванов Й. [Ivanov Y.] (1959), Българските народни песни [Balgarskite narodni pesni], Coфия.

Ивић М. [Ivić M.] (1999), Бело као лингвистички и культуролошки проблем [Belo kaо lingvistički i kulturološki problem], «Јужнословенски филолог», LX, с. 1-19.

Ивић М. [Ivić M.] (2001), О метафоричним екстензијама назива боја [O metaforičnim ekstenzijama naziva boja], «Кодови словенских култура», бр. 6: Боје, с. 7-13.

Јанковић J. [Janković J.] (2011), Семантичка анализа деривата придева бео у српском језикy [Semantička analiza derivata prideva beo u srpskom jeziku], «Прилози проучавања језика», 42, с. 9-36.

Карпіловська Є.A. [Karpilovska Ye.A.] (2002), Кореневий гніздовий словник украӥнської мови. Гнізда слів з омографічними коренями [Korenevyi hnizdovyi slovnyk ukrainskoi movy. Hnizda sliv z omohrafichnymy koreniamy], Київ.

Кирчів Р. [Kyrchiv R.] (2002), Із фольклорних регіонів України. Нариси й статті [Iz folklornykh rehioniv Ukrainy. Narysy i statti], Львів.

Клепикова Г.П. [Klepikova G.P.] (2006), К завершению проекта «Общекарпатский диалектологический атлас» $[K$ zaversheniyu proekta «Obshchekarpatskij dialektologicheskij atlas»], [в:] Общеславянский лингвистический атлас. Материаль и исследования. 2003-2005. Москва, с. 52-79.

Клепикова Г.П. [Klepikova G.P.] (2002), Многоязыковые атласы как источник изучения сеnаратных межславянских лексико-семантических параллелей [Mnogoyazykovye atlasy kak istochnik izucheniya separatnyh mezhslavyanskih leksiko-semanticheskih parallelej], [в:] Аванесовский сборник, Москва, с. 111-118.

Коспартова М. [Kospartova M.] (1972), Лексико-семантични противопоставяния в семантичната структура на лексемата бял [Leksiko-semantichni protivopostavyaniya $v$ semantichnata struktura na leksemata byal], «Български език», кн. I-II, с. 80-85.

Лесюк M. [Lesiuk M.] (2010), Еротизм в украӥнському пісенному фольклорі: лінгвістичний acnекm [Erotyzm v ukrainskomu pisennomu folklori: linhvistychnyi aspekt], Івано-Франківськ.

Лесюк M. [Lesiuk M.] (2008), Мовний світ сучасного галицького села (Ковалівка Коломийського району) [Movnyi svit suchasnoho halytskoho sela (Kovalivka kolomyiskoho rajonu)], Івано-Франківськ.

Лесюк М. [Lesiuk M.] (2008), Назви коханої людини в сучасній українській мові [Nazvу kokhanoi liudyny v suchasnii ukrainskii movi], Ucrainica, т. III: Současná ukrajinistika. Problémy jazyka, literatury a kultury, č. 1, Olomouc, c. 35-41.

Мовчанюк B. [Movchaniuk V.] (2004), Народнопісенний Дунай в поезї Шевченка [Narodnopisennyi Dunai v poezii Shevchenka], «Народна творчість та етнографія» ч. 3, с. 45-49. 
Мушкетик Л. [Mushketyk L.] (2013), Фольклор украӥнсько-угорського порубіжжя [Folklor ukrainsko-uhorskoho porubizhzhia], Київ.

Нимчук B.B. [Nimchuk V.V.] (1988), Карпатоукраинско-южнославянские языковые параллели и тождества (история и перспективы проблемы) [Karpatoukrainsko-yuzhnoslavyanskie yazykovye paralleli i tozhdestva (istoriya i perspektivy problemy)], [в:] Oбщеславянский лингвистический атлас. Материаль и исследования, Москва, с. 294-313.

Німчук B.B. [Nimchuk V.V.] (2003), Проблема карпатоукраӥнсько-південнослов'янських лексичних паралелей і збігів [Problema karpatoukrainsko-pivdennoslovianskykh leksychnykh paralelej i zbihiv], «Українська мова», № 3-4, с. 18-31.

Німчук B.B. [Nimchuk V.V.] (1993), Украӥнські говори та балканський мовний союз [Ukrainski hovory ta balkanskyi movnyi sojuz], [в:] ХI Міжнародний з'їд славістів. Слов'янське мовознавство. Доповіді, Київ, с. 41-63.

Оссовецкий И.А. [Ossoveckij I.А.] (1958), Язык фольклора и диалект [Yazyk folklora i dialekt], [в:] Основные проблемы эпоса восточных славян, Москва, с. 172-190.

Панькевич I. [Pankevych I.] (1955), Українсько-болгарські мовні зв'язки в Семигороді [Ukrainsko-bolharski movni zviazky v Semyhorodi], «Slavia», r. XXIV, № 2-3, c. 211-240.

Плотникова A.A. [Plotnikova A.A.] (2013), Южные славяне в балканском и общеславянском контексте: этнолингвистические очерки [Yuzhnye slavyane $v$ balkanskom i obshcheslavyanskom kontekste: etnolingvisticheskie ocherki], Москва.

Поповић Љ. [Popović Lj.] (2001), О семантици назива за боје у руском, украјинском и српском фолклору [O semantici naziva za boje u ruskom, ukrajinskom i srpskom folkloru], «Кодови словенских култура», бр. 6: Боје, с. 7-13.

Раденкович Л. [Radenkovich L.] (2007), Белое и черное как признаки мифологических существ (на славянском материале) [Beloe i chernoe kak priznaki mifologicheskih sushchestv (na slavyanskom materiale)], [в:] Балканские чтения. Terra balcanica. Terra slavica. К юбилею Татьяны Владимировны Цивьян, Москва, с. 80-92.

Седакова И.А. [Sedakova I.A.] (2000), О сладком в языке и культуре болгар [O sladkom $v$ yazyke i kulture bolgar], «Etnolingwistyka. Problemy języka i kultury», 12, c. 155-166.

Седакова И.А. [Sedakova I.A.] Система иветообозначений в болгарском языке [Sistema cvetooboznachenij v bolgarskom yazyke], [в:] Наименования ивета в индоевропейских языках: Системный и исторический анализ, Москва, с. 185-197.

Седакова И. А. [Sedakova I.A.] (2012), Сладкий [Sladkij], [в:] Славянские древности. Этнолингвистический словарь в $5 \mathrm{~m}$. [Slavyanskie drevnosti. Etnolingvisticheskij slovar в $5 \mathrm{~m}$.], т. 5, Москва, с. 33-39.

Толстая C.M. [Tolstaya S.M.] (2008), Пространство слова. Лексическая семантика в общеславянской перспективе [Prostranstvo slova. Leksicheskaya semantika v obshcheslavyanskoj perspektive], Москва.

Толстой Н.И. [Tolstoj N.I.] (1995), Бельй иявет [Belyj tsvet], [в:] Славянские древности. Этнолингвистический словарь в $5 \mathrm{~m}$. [Slavyanskie drevnosti. Etnolingvisticheskij slovar в $5 \mathrm{~m}$.], т. 1, Москва, с. 151-154.

Шумада H.C. [Shumada N.S.] (1969), Пісенні мініатюри украӥнського народу [Ріsеnпі miniatiury ukrainskoho narodu], [в:] Коломийки, упор. Н.С. Шумада, Київ, с. 11-43.

Bartmiński J. (1973), O języku folkloru, Wrocław - Warszawa - Kraków - Gdańsk.

Bartmiński J. (1990), Folklor - język - poetyka, Wrocław - Warszawa - Kraków. 
Ivić M. (1995), O zelenom konju. Novi lingvistički ogledi, Beograd.

Jagić V. (1876), Dunav - Dunaj in der slavischen Volkspoesie, «Archiv für slavische Philologie», B. I, H. 2, s. 299-333.

Siatkowski J. (2001), Karpacki atlas dialektologiczny, [в:] Złota księga. Ścieżkami współczesnego literaturoznawstwa i językoznawstwa, red. S. Gajda, Opole, s. 349-358.

Sierociuk J. (1990), Peśń ludowa i gwara, Lublin. 